Florida International University FIU Digital Commons

$11-26-2002$

\title{
Dietary folate intake of firefighters in Metro-Dade county and their risk for cardiovascular disease
}

Kathrine Berdebes

Florida International University

DOI: $10.25148 /$ etd.FI15011400

Follow this and additional works at: https://digitalcommons.fiu.edu/etd

Part of the Dietetics and Clinical Nutrition Commons

\section{Recommended Citation}

Berdebes, Kathrine, "Dietary folate intake of firefighters in Metro-Dade county and their risk for cardiovascular disease" (2002). FIU Electronic Theses and Dissertations. 2430.

https://digitalcommons.fiu.edu/etd/2430 


\section{FLORIDA INTERNATIONAL UNIVERSITY}

Miami, Florida

DIETARY FOLATE INTAKE OF FIREFIGHTERS IN METRO-DADE COUNTY AND THEIR RISK FOR CARDIOVASCULAR DISEASE

A thesis submitted in partial fulfillment of the

requirements for the degree of

MASTER OF SCIENCE

in

DIETETICS AND NUTRITION

by

Kathrine Berdebes 
To: Dean Ronald M. Berkman

College of Health and Urban Affairs

This thesis, written by Kathrine Berdebes, and entitled Dietary Folate Intake of Firefighters in Metro-Dade County and their Risk for Cardiovascular Disease, having been approved in respect to style and intellectual content, is referred to you for judgment.

We have read this thesis and recommend that it be approved.

Dian Weddle

David Lee

Fatma Huffman, Major Professor

Date of Defense: November 26, 2002

The thesis of Kathrine Berdebes is approved.

Dean Ronald M. Berkman

College of Health and Urban Affairs

Dean Douglas Wartzok
University Graduate School

Florida International University, 2002 


\section{DEDICATION}

I dedicate this thesis to my family and friends whom I love dearly. Without their love, patience, understanding, support, and faith in me, this work would have never been written. I would like to especially mention my sister, Christina Berdebes. For without her unfailing support, love, and understanding, this would have never been finished. Thanks to my parents and brother, Michael Berdebes, Eulalia Aguas Vallejo de Berdebes and Michael V. Berdebes Jr., for their love, encouragement and faith in me. I would also like to thank my Ecuadorian and Greek Grandmothers, Emma Vallejo Lopez de Aguas and Gianoula Souryiani, who inspired me to excel and taught me to appreciate cultural

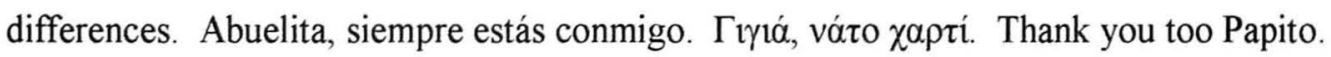




\section{ACKNOWLEDGMENTS}

I would like to sincerely thank my committee members for their patience, understanding, and helpful contributions. Dr. Dian Weddle was particularly helpful in guiding me toward a noteworthy methodology. Dr. David Lee from the Epidemiology Department from the University of Miami not only served as a kind liaison to MetroDade Firefighters but also provided enlightening criticism. Finally, I would like to thank my major professor Dr. Fatma Huffman, who first told me of the FIU Master of Science in Dietetics and Nutrition and Dietetic Internship program and encouraged my entry therein. She has helped in ways too numerous to mention. She has always had time for my problems and gave all the advice and support that I needed to finish this work. From the beginning of my studies here, she has been confident of my abilities to excel, and here at the end, she helped usher me out with diligent and incisive comments and unfailing kind encouragement.

I am also greatly indebted to Dr. Paulette Johnson of the Statistics Department and her graduate assistant Karla Llarena for their assistance and positive attitude towards my work. Last but not least, I would like to thank the Metro-Dade Firefighters who participated enthusiastically in this study. 


\section{ABSTRACT OF THE THESIS}

\section{DIETARY FOLATE INTAKE OF FIREFIGHTERS IN METRO-DADE COUNTY AND THEIR RISK FOR CARDIOVASCULAR DISEASE}

by

Kathrine Berdebes

Florida University, 2002

Miami, Florida

\section{Professor Fatma Huffman, Major Professor}

The purpose of this study was to show variations of folate intake, folate food sources, and diet by age, gender, and ethnicity in Metro-Dade Firefighters and to also determine the prevalence of obesity, physical inactivity and history heart disease. Low folate status may play a role in cardiovascular risk via its effect on homocysteine metabolism. Firefighters $(\mathrm{n}=127)$ recruited from randomly selected fire stations completed food-frequency and socio-demographic questionnaires. Significantly $(p<.05)$ more African-Americans failed to meet at least $75 \%$ of the dietary reference intake (DRI) for folate than whites or Hispanics. There were significant differences in protein, vegetable, and meat intakes between age groups. Almost $78 \%$ of firefighters were overweight $(\mathrm{BMI} \geq 25)$. There were significant $(\mathrm{p}<.001)$ differences in BMI among ethnic groups. Older firefighters reported significantly $(p<.05)$ more CVD risk factors than younger firefighters. Metro-Dade firefighters were found to be similar to the general US population in that most of the risk factors, overweight and obesity, high fat intakes, and low folate intake were modifiable and diet related. 


\section{TABLE OF CONTENTS}

CHAPTER

PAGE

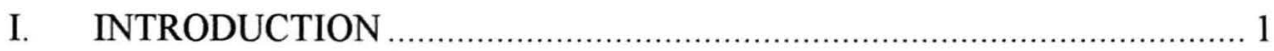

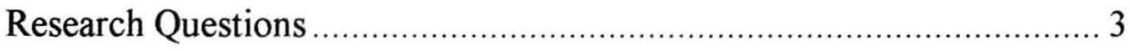

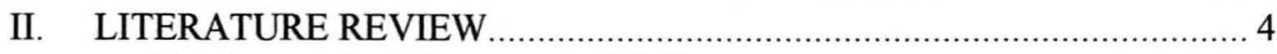

Cardiovascular Disease and Risk Factors ............................................. 4

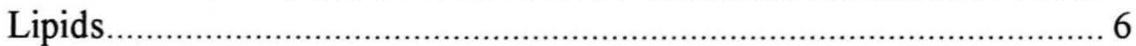

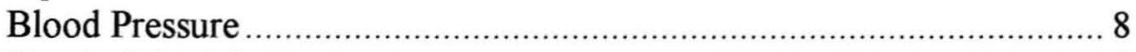

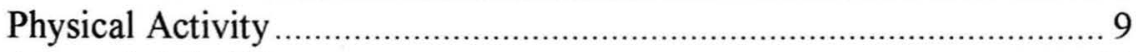

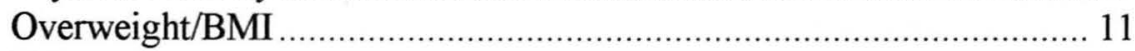

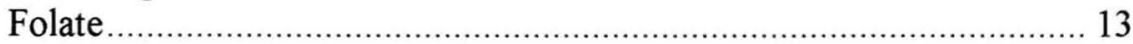

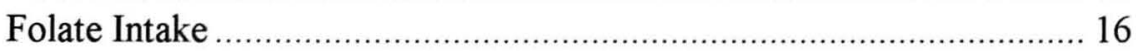

Firefighters and Risk for Cardiovascular Disease ................................ 17

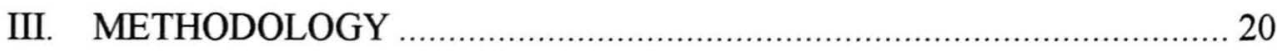

Study Design and Subject Selection ................................................ 20

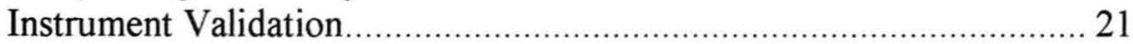

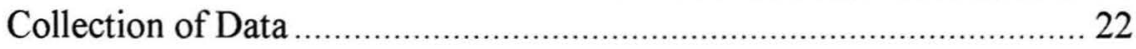

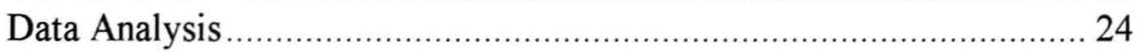

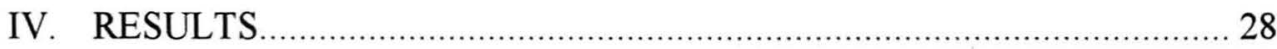

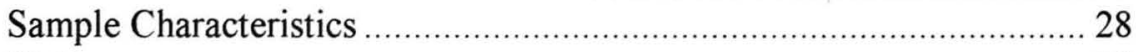

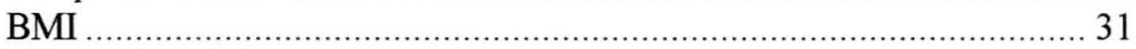

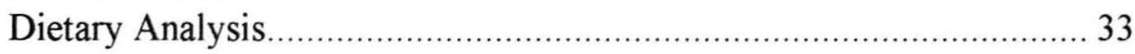

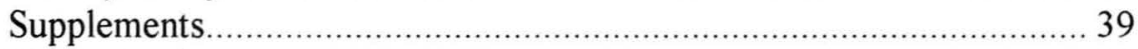

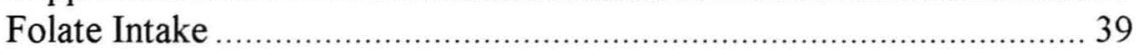

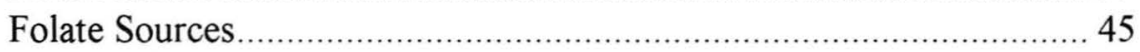

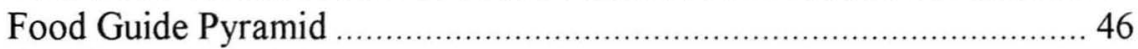

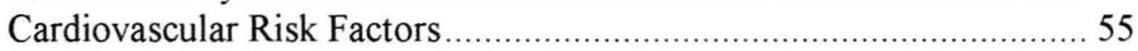

V. DISCUSSION

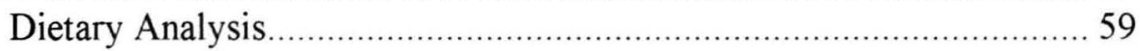

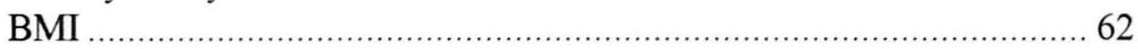

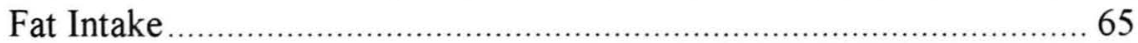

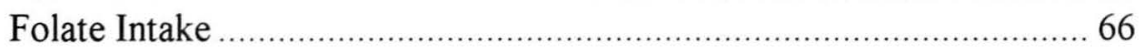

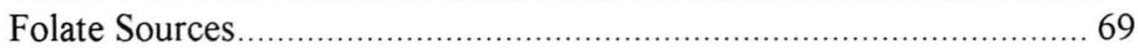

Nutrient Intake and Supplement Use ........................................... 70

Cardiovascular Risk Factors ......................................................... 71

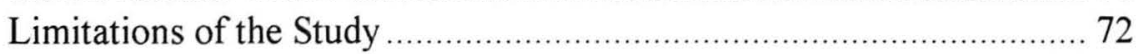

Summary of Significant Findings .................................................. 73 
LITERATURE CITED

APPENDICES

84 


\section{LIST OF TABLES}

\section{TABLE}

PAGE

1. Randomization of Fire Stations 29

2. Gender and Ethnic Distribution of Metro-Dade Firefighters 30

3. Highest Education Level Attained by Metro-Dade Firefighters 30

4. Length of Time of Metro-Dade Firefighters Living in the US 32

5. Body Mass Index by Gender and Ethnicity, Metro-Dade Firefighters. 32

6. Calorie and Macronutrient Intake of Metro-Dade Firefighters .35

7. Calorie and Macronutrient Intake by Age, Metro-Dade Firefighters 36

8. Micronutrient Intake of Metro-Dade Firefighters 37

9. Percent of Metro-Dade Firefighters Reporting Intake of Supplements 38

10. Percentage of Metro-Dade Firefighters Meeting the DRI for Folate from Food Intake, by Age

11. Percentage of Metro-Dade Firefighters Meeting the DRI for Folate from Food and Supplement Intake, by Age

12. Percentage of Metro-Dade Firefighters Meeting the DRI for Folate from Food Intake, by Gender

13. Percentage of Metro-Dade Firefighters Meeting the DRI for Folate from Food and Supplement Intake, by Gender

14. Percentage of Metro-Dade Firefighters Meeting the DRI for Folate from Food Intake, by Ethnicity

15. Percentage of Metro-Dade Firefighters Meeting the DRI for Folate from Food and Supplement Intake, by Ethnicity.

16. Major Food Contributors of Folate in the Diet of Metro-Dade Firefighters .45

17. Mean Numbers of Food Guide Pyramid Servings Consumed per Day, by Age, Metro-Dade Firefighters 
18. Grain: Percentage of Individuals Consuming Specified Numbers of Pyramid Servings per Day, by Gender and Age, Metro-Dade Firefighters and USDA Continuing Survey of Food Intake by Individuals, 1994-96, 98

19. Vegetable: Percentage of Individuals Consuming Specified Numbers of Pyramid Servings per Day, by Gender and Age, Metro-Dade Firefighters and USDA Continuing Survey of Food Intake by Individuals, 1994-96, 98

20. Fruit: Percentage of Individuals Consuming Specified Numbers of Pyramid Servings per Day, by Gender and Age, Metro-Dade Firefighters and USDA Continuing Survey of Food Intake by Individuals, 1994-96, 98 .50

21. Dairy: Percentage of Individuals Consuming Specified Numbers of Pyramid Servings per Day, by Gender and Age, Metro-Dade Firefighters and USDA Continuing Survey of Food Intake by Individuals, 1994-96, 98

22. Meat: Percentage of Individuals Consuming Specified Numbers of Pyramid Servings per Day, by Gender and Age, Metro-Dade Firefighters and USDA Continuing Survey of Food Intake by Individuals, 1994-96, 98

23. Pyramid Tip - Fat: Mean Daily Intakes of Fat, by Gender and Age, Metro-Dade Firefighters and USDA Continuing Survey of Food Intake by Individuals, 1994-96, 98

24. Percent of Metro-Dade Firefighters Reporting Risk Factors for Coronary Heart Disease 56

25. The Mean Number of Risk Factors for Coronary Heart Disease, by age, MetroDade Firefighters 


\section{CHAPTER I \\ INTRODUCTION}

Cardiovascular disease (CVD) is the leading cause of mortality in the United States (AHA, 1999). Over 200 risk factors of CVD have been identified (Castelli, 1996). In addition to abnormal lipids, blood pressure, and cigarette smoking, other known, conventional risk factors for CVD such as dietary fat and cholesterol intake, physical activity level, overweight reported as body mass index (BMI), and especially serum homocysteine level, which has been associated with folate, have become increasingly significant. Although, limited studies have been done on firefighters, CVD risk factors have been found to be in high-risk range and increased frequency in firefighters (Glueck et al, 1996; Weiss et al, 1984). Their lack of nutritional knowledge about differences between various kinds of dietary fat is reflected in their diet which has been found to be high in total fat, saturated fat, cholesterol, and sodium.(LoCastro, 1989; Weiss, 1984). Diets may also be low in fruits and vegetables, which are major sources of folate. Therefore, it may be wise to assess diet as a modifiable CVD risk factor for this population.

Although all three National Health and Nutrition Examination Surveys (I, II, and III) (NHANES) have examined folate intake, only the third looked at ethnicity. Albeit numerous cultures are found in the US, it only investigated blacks, whites, and Hispanics. Furthermore, the Hispanic group embodies diverse cultures, yet studies have been typically limited to Mexican-Americans. Since culture plays a role in food preferences, ethnic differences may be an important consideration in dietary intake studies. 
Folate intake has increased from the second NHANES survey. Although almost $88 \%$ of American adults still consume less than the RDA (1989) for folate, with particularly low intake among women and African-Americans (Subar et al, 1989). However, the increase in folate levels found in the NHANES III has been questioned due to methodological differences in dietary recall (Ford and Ballew, 1998). Furthermore, part of this increase can be attributed to the new fortification policy, which as of January 1, 1998 mandates the fortification of cereal grain products in the US food supply with folic acid (Federal Register, 1996)

Several studies including a meta-analysis have found plasma homocysteine levels to be an independent risk factor for cardiovascular disease (Boushey et al, 1995; Dalery et al, 1995; Verhoef et al, 1998). Since dietary folate has been found to be inversely related with plasma homocysteine levels (Boushey et al, 1995; Dalery et al, 1995; Tucker et al, 1996; Selhub et al, 1995; Selhub et al, 1993), low intakes of folate may also play a role in cardiovascular risk. Consequently, adequate intakes of fruits, green leafy vegetables, breakfast cereals, and multivitamins have been found to be inversely associated with homocysteine levels (Tucker et al, 1996). It is not surprising that a metaanalysis of folate and homocysteine studies found that if the population consumed 2-3 servings of fruits and vegetables daily, 15,000 potential CVD deaths in men and 11,500 in women could be prevented (Boushey et al, 1996).

Assessing the dietary folate status of firefighters, using the Willett food-frequency questionnaire, and recording anthropometric as well as socio-demographic data may further support previous research indication that this population may be at increased risk for CVD. No nutritional epidemiological studies have examined ethnic differences in 
these risk factors among firefighters. Determining which folate sources are predominant in certain ethnic groups and genders may also help registered dietitians develop nutrition intervention programs to help this population to increase their folate intake and thus reduce their risk for CVD.

\section{Purpose of The Study}

To show variations of folate intake, folate food sources, and diet by age, gender, and ethnicity in Metro-Dade Firefighters and to also determine the prevalence of obesity, physical inactivity and history heart disease.

\section{Research Questions:}

1. What is the mean folate intake of firefighters and how does it compare to appropriate intake data for the general US population?

2. What are the variations of folate intake and folate food sources by age, gender, and ethnicity of firefighters?

3. What are their predominant sources of dietary folate? How many servings of fruits, vegetables, and breakfast cereals, which are high in folate, do firefighters consume?

4. What percentage of firefighters take nutritional supplements and, among those that do, what type of supplements do they take?

5. What is the percentage of fat, carbohydrate, and protein in their diet? How many servings of each food group cereals and grains, fruits and vegetables, dairy, meat, and fat do firefighters consume and how does it compare to appropriate intake data for the general US population?

6. Which known. conventional cardiovascular risk factors as indicated by the American Heart Association Cardiac Risk Evaluation Questionnaire (CREQ) and current literature are prevalent in Metro-Dade Firefighters? 


\section{CHAPTER II}

\section{LITERATURE REVIEW}

\section{Cardiovascular Disease and Risk Factors}

Almost 60 million or 1 in 5 Americans have one or more types of cardiovascular diseases (CVD), which include high blood pressure, coronary heart disease, and stroke. Although death rates from CVD declined 21.3\% from 1986 to 1996, it is still the leading cause of mortality in the US. In $1996,41.4 \%$ of all deaths were attributed to CVD. One form of CVD, coronary heart disease (CHD) accounts for one-third of all deaths annually (PHS, 1992). The economic burden of CHD is also considerable; related medical care costs and lost earnings were estimated to be $\$ 56.3$ billion in 1994 (AHA, 1999).

The 1999 age adjusted death rate from CVD for the US population is 365.4 per 100,000 and for the state of Florida is 332.4. Although Florida's average annual percent change of CVD death rate for the years 1989 to 1999 show a decline of $18.9 \%$, its rank of 17 in 1940 rose to 16 in 1999. Perhaps, Florida has a larger population of older adults, who may be more prone to CVD. However, its rank from CHD of 28 in 1940 dropped to 33 in 1999. (AHA, 2001). Ethnic differences must be considered as well. The age adjusted CHD death rates in Florida in 1992 for whites, blacks, and Hispanics were 105.4, 149.6, and 78.1 respectively. Although the rate for Hispanics increased in 1995 to 81.1, the rates for whites and blacks declined to 101.4 and 148.3 (CDC, 1999).

Over 200 risk factors for CVD have now been identified. Among these, the three most important are (1) abnormal blood lipids, including more than 15 types of cholesterol-containing lipoproteins and four different types of triglyceride-rich particles, 
some of which are very atherogenic, (2) high blood pressure, and (3) cigarette smoking. (Castelli, 1996).

The Multiple Risk Factor Intervention Trial (MRFIT) was a randomized, primary prevention trial that investigated these three risk factors. MRFIT was conducted at 22 US clinical centers from 1973 to 1982 to test whether lowering elevated serum cholesterol and diastolic blood pressure and ceasing cigarette smoking would reduce CHD mortality in men, $35-57$ years of age. Although CHD mortality in men at $10.5 \mathrm{yr}$. who received the special intervention (SI) was $10.6 \%$ lower than for men who received usual care (UC), this difference was not statistically significant. However, there was a significantly lower rate, $24.3 \%$, in SI men for acute myocardial infarction, a sub-category accounting for more than half of $\mathrm{CHD}$ deaths. By year 16, the lower rate for acute myocardial infarction continued to be significant (Kjelsberg et al, 1997).

In addition to the three major risk factors, other important factors such as dietary fat intake, physical activity level, overweight, alcohol, and blood homocysteine have also been examined in numerous studies. Recently, folate status has been given much attention because it may play a role in cardiovascular risk via its effect on homocysteine metabolism. Therefore, in identifying individuals at risk for CVD, especially those that may be at high risk, it may be sensible to examine all of the risk factors implicated. Considering, that many of these are diet-related, it is imperative that their diets are not overlooked.

Kumanyika (1993) suggested that there might be racial and ethnic differences in diet-related attributable risks. "The significance of diet and nutrition for the health status of minority populations may be greater than for whites because of a higher prevalence of 
risk factors or, in some cases, because the sensitivity to a given risk-factor may be greater" (Kumanyika, 1993). Although a few nutritional epidemiologic studies have compared racial or ethnic groups, further research is needed to explore of the role of diet and nutrition in relation to health disparities between minorities and whites.

\section{Lipids}

Although the entire lipid profile is usually examined to identify those individuals with an increased risk for CVD, it has been suggested that the ratio of total cholesterol to HDL cholesterol followed by the measurement of plasma triglycerides concentrations are most important (Castelli, 1996). However, studies have also indicated that dietary cholesterol and saturated fat must be considered as well. In the Seven Countries Study, (Kromhout et al, 1995), associations between intake of individual fatty acids and dietary cholesterol were studied in relation to serum cholesterol and 25-year mortality from $\mathrm{CHD}$. Strong positive associations were observed between 25-year death rates from CHD and average intake of the four major saturated fatty acids, lauric, myristic, palmitic, and stearic acid, and dietary cholesterol (Kromhout et al, 1995).

Although the media has led many Americans to believe that "no cholesterol" products decrease their risk for CVD, saturated fat intake must be considered as well. A study done by McCarron et al, (1995) found that the consumption of products marketed as "No Cholesterol" with high total and saturated fat clearly does not contribute to the optimal diet for reducing plasma cholesterol levels of risk of atherosclerosis. Accordingly, the American Dietetic Association, American Heart Association, and National Heart, Lung, and Blood Institute, have recommended Americans to follow a 
low-fat 5 low-cholesterol diet, restricting saturated fat intake to less than $10 \%$ of energy consumed and overall dietary fat intake to $30 \%$ or less (NRC, 1989).

Data from the NHANES III suggest that Americans are making some progress towards these goals. Whereas in the NHANES II, 1976-1980, mean intake of saturated fat and total dietary fat was $16 \%$ and $37 \%$ of the total energy intake, the first phase of the NHANES III, 1988-1991, indicated a decline in the intakes to $12 \%$ and $34 \%$, respectively (PHS, 1983; Lenfant, 1991).

Although information on ethnic differences from NHANES was limited, Croft et al, (1994) has suggested that saturated fat intake may be higher in blacks than whites. A cross-sectional data was collected via telephone surveys in two South Carolina communities to determine trends in dietary fat consumption among black and whites (Croft et al, 1994). Ethnic-specific adjusted prevalence of dietary fat used differed between ethnic groups. White respondents had a greater prevalence of using liquid or soft vegetable fats, or nonstick sprays whereas the prevalence of using animal fats was greater in black respondents. The prevalence of using solid vegetable fats did not differ between ethnic groups during any survey (Croft et al, 1994).

Without any direct intervention to reduce dietary fat intake or other coronary risk factors, Oster et al, (1996) estimates that 3 million people in their study cohort, with cholesterol levels exceeding $5.17 \mathrm{mmmol} / \mathrm{L}$, will develop symptomatic $\mathrm{CHD}$ over the next 10 years. Based on their findings, they also suggest that if Americans reduce saturated fat intake from current levels to $9 \%$ of total energy intake, about 100,000 first-time coronary events could be averted by the year 2005 , with associated cost savings of approximately $\$ 13$ billion (in 1993 dollars). 
Approximately 50 million or 1 in 4 adults have high blood pressure based on the NHANES III, or 30 to 40 million based on the fifth report of the Joint National Committee on detection, Evaluation, and Treatment of High Blood Pressure criteria (NIH, 1993; JCDET, 1993).

Hypertension, defined as blood pressure (BP) exceeding an upper limit of normality; the upper limit is generally accepted as systolic BP $>140 \mathrm{~mm} \mathrm{Hg}$ and/or diastolic $\mathrm{BP}>90 \mathrm{~mm} \mathrm{Hg}$, is one of the most prevalent and powerful contributors to cardiovascular diseases (JCDET, 1993; Kannel, 1996). Its contribution increases risk, on average, 2- to 3-fold, for all major atherosclerotic cardiovascular disease outcomes, including cardiac failure, strokes, coronary disease, and peripheral artery disease. Approximately $35 \%$ of atherosclerotic cardiovascular events may be attributed to hypertension (Kannel, 1996)

Systolic and diastolic BP increase progressively with age in the US. There is, on average, a $20 \mathrm{mmHg}$ systolic and $10 \mathrm{mmHg}$ diastolic increase in blood pressure from age 35 to 65 years (Kannel, 1996; Preuss et al, 1996). The prevalence of hypertension is also higher in blacks than whites. Women have lower blood pressure measurements than men in early adult life, but their blood pressures increase more steeply with age to reach or exceed those of men beyond middle age (JCDET, 1993). There is no evidence of a decline in the prevalence of hypertension over four decades despite improvements in its detection and treatment (Kannel, 1996; JCDET, 1993).

Coexistence of risk factors exerts a greater influence on cardiovascular hazards than high blood pressure alone. Hypertension is only one of many risk factors involved in 
atherogenesis and the risk of raised blood pressure varies widely depending on the number and severity of coexistent atherogenic risk factors (Kannel, 1996). An association between weight and elevated blood pressure and other risk factors for CVD has been well-established (Larsson et al, 1984; Stamler, 1991; Labarthe et al, 1991). For example, relative risk for developing hypertension is five times greater in obese individuals than normal-weight adults (Stamler et al, 1978). About 50\% of the coronary events in hypertensive patients occur in those who are in the upper quartile of multivariate risk (Kannel, 1996)

Hypertension has been widely investigated in whites and blacks; however, few studies have focused on minorities, such as Hispanics and Asians, and its relation to acculturation. Although hypertension is rare in some non-acculturated societies, (Tuomilheto et al, 1989), it develops when these groups become more "Westernized" or when individuals from these cultures migrate to more acculturated societies, strengthening the concept that not only genetic factors but environmental considerations are also important (Preuss et al, 1996). Nutrition is an important consideration as an approach to preventing and treating hypertension (Hodges et al, 1985; Appel et al 1997). A diet rich in fruits, vegetables, low-fat dairy foods with reduced saturated and total fat can substantially lower blood pressure (Appel et al, 1997) and thereby decrease the risk of CVD.

Physical Activity

Considering that 1 in 3 Americans is overweight, it would not be plausible to describe the American lifestyle as sedentary (Kuczmarski et al, 1994). The Center for Disease and Control (CDC) (1992) analyzed data on self-reported leisure-time physical 
activity from the Behavioral Risk Factor Surveillance System and indicated that, in 1991, $58.1 \%$ of adults reported irregular or no leisure time physical activity. Studies indicate that lack of physical activity may be a CVD risk factor (Godlands et al, 1998;

Paffenbarger et al, 1993). Regular participation in moderate-intensity activities, such as walking and gardening has been associated with a reduced risk of primary cardiac arrest (Lemaitre et al, 1999). Therefore, increasing their physical activity may not only help Americans lose weight but also help reduce their risk for CVD.

Level of physical activity as a risk factor for CVD has also been examined in conjunction with other risk factors such as cigarette smoking, blood pressure, and alcohol intake. As part of the Heart Disease and Diabetes Risk Indicators in a Screened Cohort study (HDSC-1), the associations between risk factors for CVD and cigarette smoking, alcohol intake, and physical activity were investigated in a cohort of 742 men (Godlands et al, 1998). Results indicated that previous cigarette smoking was independently associated with high uric acid and low HDL cholesterol, and current cigarette smoking with high hemoglobin and white cell count and low oral glucose tolerance test (OGTT). Increased alcohol intake was associated with increased blood pressure, uric acid, HDL cholesterol and fasting glucose. Moderate exercise was associated with decreasing systolic blood pressure, fasting insulin, OGTT glucose and insulin (Godlands et al, 1998). Although HDL cholesterol has been shown to be positively related to moderate alcohol consumption in other studies as well, it is suggested that efforts to reduce CHD risks should concentrate on other risk factors such as smoking and weight control (Linn, 1993). 
Paffenbarger et al, (1993) examined changes in level of physical activity, cigarette smoking, blood pressure, and body weight, and the relation of these factors to mortality. Subjects were 10,269 male who were 45 to 84 years of age in 1977 and alumni of Harvard University that completed questionnaires regarding lifestyle characteristics in 1962 or 1966 and again in 1977. The associations between changes in lifestyle and mortality were independent. Beginning moderately vigorous sports activity, quitting cigarette smoking, maintaining normal blood pressure, and avoiding obesity were separately associated with lower rates of death from all causes and from CHD among middle-aged and older men.

There were 130 deaths from physician-diagnosed CHD during the follow-up period from 1977 to 1985 . Sedentary alumni were at $36 \%$ higher risk to die from CHD than active men. Meanwhile, those who did not engage in moderately vigorous sports activity were at $51 \%$ higher risk to die from CHD than men who did. Quitting smoking was associated with a $41 \%$ lower risk than continuing smoking, but with a $23 \%$ higher risk than constant nonsmoking. As expected, maintenance of lean body mass was associated with a lower mortality rate than long-term, or previous obesity. Overweight/BMI

Over $33 \%$ of Americans aged 20 years and older are overweight and much of the increase occurred in the past decade (Kuczmarski et al, 1994). Although the diet industry has benefited financially, the prevalence of overweight has burdened the US health care system (Pi-Sunyer, 1991). Increased levels of overweight, reported as body mass index, are associated with increased cardiovascular risk factors of high blood pressure and high blood cholesterol (Ernst et al, 1997). Consequently, the risk for a variety of chronic 
diseases and mortality has been associated with increases in body mass index (BMI) (Manson et al, 1990; Rissanen et al, 1989).

Trends in overweight prevalence and BMI were examined in the US adult population in NHANES I, II, and III. Although NHANES II statistically defined overweight as BMI $\geq 27.8 \mathrm{~kg} / \mathrm{m}^{2}$ for men and BMI $\geq 27.3 \mathrm{~kg} / \mathrm{m}^{2}$ for women (Kuczmarski et al, 1997), it is more commonly defined as BMI $\geq 25$ (NIH, 1998). Data from NHANES III, phase I, on blood lipid levels and blood pressure in the US population showed declines in the prevalence of hypertension and high blood cholesterol, despite the increased prevalence of overweight (JNCDET, 1993; Johnson et al, 1993).

Results from NHANES III, 1988 to 1991, indicated median BMI for U.S. adults aged 20 years and older to be $25.5 \mathrm{~kg} / \mathrm{m}^{2}$. The percentage of the population that was classified as underweight (BMI < 19.0) was $1.6 \%$ for men, $5.7 \%$ for women. Only $39.0 \%$ of men and $43.6 \%$ of women were at a healthy weight, BMI between 19.0 and 25.0. More than half or an estimated 97.1 million adults were at least moderately overweight, as defined by a BMI $\geq 25.0$ (Kuczmarski et al, 1997).

Unlike past surveys, NHANES III examined ethnic/racial differences. However, despite the fact that Hispanics consists of numerous and diverse cultures, only MexicanAmericans were examined. The unadjusted prevalence of overweight was similar for non-Hispanic white men (32.3\%) and non-Hispanic black men (30.9\%), but was higher for Mexican-American men (35.5\%). Ethnic differences were greater among women. The prevalence of overweight ranged from $32.9 \%$ for non-Hispanic white women to $46.7 \%$ for Mexican-American women and $48.6 \%$ for non-Hispanic black women (Kuczmarski et al, 1994). Considering the extensive prevalence of overweight in the US, 
it was not surprising that the Healthy People 2000 objective of no more than $20 \%$ of US adults overweight was not met for the year 2000 (Healthy People, 2010).

Folate

Plasma and dietary folate have been found to be inversely related with plasma homocysteine levels (Boushey et al, 1995; Dalery et al, 1995; Tucker et al, 1996; Selhub et al, 1993; Selhub et al, 1995). Several studies including a meta-analysis have found homocysteine to be an independent risk factor for cardiovascular disease (Boushey et al, 1995; Dalery et al, 1995; Verhoef et al, 1998). Low folate status may play a role in cardiovascular risk via its effect on homocysteine metabolism (Boushey et al, 1995; Brussard et al, 1997, Chasen-Tuber et al, 1996; Jacobsen, 1996). Thus, assessing folate intake in firefighters may be meaningful because they may be at high risk for CVD.

The Framingham Heart study has suggested that folate and homocysteine status and risk for cardiovascular disease may be improved by increased dietary folate intake (Tucker et al, 1996). Rather than encouraging folic acid supplement use, emphasis was placed on the consumption of more fruits, vegetables, and cereals to increase folate intake and decrease homocysteine levels. Additional benefits from increased fruit and vegetable intake on health would also be experienced from the variety of nutrients they provide such as vitamin $\mathrm{A}$, vitamin $\mathrm{C}$, and fiber.

The top sources of folate for 885 elderly subjects in the Framingham Heart study, were identified as supplements, breakfast cereals, orange juice, and green leafy vegetables (including broccoli). Multivitamin users ( $25 \%$ of the subjects) had the highest folate intake, plasma folate levels, and lowest homocysteine concentrations. The use of breakfast cereals at least twice a week was associated with lower homocysteine levels. 
Orange juice was associated with plasma folate but not lower homocysteine. Green leafy vegetables were associated with higher plasma folate and lower homocysteine levels.

After adjusting for age, gender, total energy intake, and use of folate supplements, plasma folate and homocysteine concentrations significantly increased with frequency of intake of breakfast cereals, fruits, and vegetables. However, concentrations peaked and remain unchanged at 6 servings of cereal per week and at 5-6 servings of fruits and vegetables per day. Consequently, this is in compliance with the National Cancer Institute (NCI) "5 a day" campaign and the "5 a Day for Better Health" program (Healthy People, 1998).

A similar study done in the Netherlands by Oshaug et al, (1998) who investigated the relationship between the intake of individual food sources of folate and plasma homocysteine concentrations on 310 healthy men with a mean age of 38 years. Bread and fresh vegetables were negatively associated with homocysteine levels; however, fat was positively associated. After controlling for age, gender, and education, bread, fresh vegetable and fat consumption were independent determinants for homocysteine (Oshaug et al, 1998).

Since dietary folate intake reflects biochemically measured folate status (Boushey et al, 1995), the inverse association between homocysteine and dietary folate found in the studies by Tucker et al, (1996) and Oshaug et al, (1998) was expected. The risk of CVD was indirectly attributed to folate's role in homocysteine metabolism. However, one study (Verhoef et al, 1998) investigated the direct relation of dietary folate intake and the risk of myocardial infarction (MI). Dietary and plasma folate were inversely associated with risk of MI, independent of other potential risk factors (Verhoef et al, 1998). However, individual food sources of folate and its relation to risk of CVD were not 
examined. Future studies should not only investigate this relationship but also should examine differences in folate intake and risk for CVD by age, gender, and ethnicity.

Assessing folate status of firefighters may further support precious research indicating that this population may be at increased risk for CVD. Determining which folate sources are predominant in certain ethnic groups and genders may also help registered dietitians (RDs) develop nutrition tailored intervention programs to help this population increase their folate intake and thus reduce their risk for CVD.

\section{Folate Intake}

Low dietary folate is the most common cause of compromised folate status (Boushey et al, 1995). A meta-analysis of folate and homocysteine studies found that if the population ate 2-3 servings of fruits and vegetables daily, 15,000 potential deaths in men and 11,500 in women could be prevented (Boushey et al, 1995). Because the " $5 \mathrm{a}$ Day for Better Health" program has been encouraging an intake of at least 5 servings of healthful fruits and vegetables (Healthy People, 2000), one would expect that many more deaths have been prevented. However, it appears that many Americans are not following the program's advice.

In 1994-96, the population aged 20 and over consumed an average of 4.9 daily servings of fruits and vegetables (USDA, 1996). The Healthy People 2000 Progress Review indicates that stating the year 2000 target of 5 servings a day has been met would be misleading because not all of those vegetable products are low in fat (Healthy People, 2000). The USDA's Continuing Survey of Food Intakes by Individuals, 1994-96, found that one-third of vegetable servings were fried potatoes (USDA, 1996). Other folate 
sources may not be compensating for the lack of fresh fruits and vegetables in the US diet.

Using NHANES II, Subar et al, (1989) examined the mean, median, and intake per $1000 \mathrm{kcal}$ (density) of folate intake by categories: gender, age, and ethnicity. Almost $88 \%$ of American adults consume less than the $1989 \mathrm{RDA}$ for folate. It was found that whites have higher folate intakes than blacks. For all categories, men have diets that are lower in folate than women. Folate intake did not increase with age but with higher education (Subar et al, 1989). Although the top sources of folate were identified and ranked by gender and ethnicity, only two ethnic groups were examined, Hispanics were not included.

Using data from the first phase of NHANES III, conducted 1988 to 1991, the dietary intake of folate in the US population was estimated and seems to have increased. Mean intake for the population aged 7 years and older was $283.4 \mathrm{mcg} /$ day; $70 \%$ met the 1989 RDA for folate $(200 \mathrm{mcg} /$ day $)$. Since the data on intake of nutritional supplements were not available, it is likely that a higher proportion of the US population met the 1989 RDA for folate (Ford, and Ballew, 1998).

Similar to past surveys, men had higher intakes of folate than women, and African-Americans had the lowest intakes compared to other ethnic groups. AfricanAmerican women had the lowest absolute intake among all. The study was limited for two reasons: 1) Hispanics were defined as Mexican-Americans; 2) Methodological differences in administering 24-hour dietary recalls in NHANES II and III limit comparisons (Ford and Ballew, 1998). However, it is evident that African-Americans 
consistently have lower intakes of folate among ethnic groups and may benefit from health interventions to increase their folate intake.

As of January 1, 1998, cereal grain products in the US food supply are being fortified with folic acid (Federal Register, 1996). Studies are needed to evaluate the effectiveness of the new fortification policy on increasing folate intake in the US population. Investigating the folate status of firefighters would not only provide the opportunity to evaluate this but given Miami's diverse population, the folate intake of many ethnic groups can be examined as well.

Firefighters and Risk for Cardiovascular Disease

Analysis of job-related diseases and occupation data from the Bureau of Labor Statistics Supplementary Data System (SSDS) reveals that fire fighting is one of the occupations contributing the most heart attack deaths (Leigh, 1998). Consequently, two studies (Glueck et al, 1996; Weiss et al, 1984) have looked at CHD risk factors in firefighters.

Glueck et al (1996) measured CHD risk factors: weight; blood pressure; cigarette use; lipid profile; every 1-4 years, in 806 firemen with a mean age of 37 years in Cincinnati, free of $\mathrm{CHD}$ at study entry. Men who had developed $\mathrm{CHD}$ had elevated systolic and diastolic blood pressure, LDL, total cholesterol, and triglycerides (TG). Age, cigarette smoking, diastolic blood pressure, and family history of $\mathrm{CHD}$ were independent predictors of $\mathrm{CHD}$ events. This study suggested that modifiable $\mathrm{CHD}$ risk factors are primarily responsible for CHD in firefighters (Glueck et al, 1996).

Although 1 in 3 men in the US can expect to develop some major CVD before age 60 (AHA, 1999), this proportion may be higher in firefighters because of their increased 
frequency of CHD risk factors such as: excess fatness; hypertension (HTN); and lipid abnormalities (Weiss et al, 1984). Weiss et al (1984) found that $52 \%$ of firefighters aged $30-59$ had excess fatness and 53\% were smokers. Of those aged $40-59$ years, $36 \%$ were hypertensive, $29 \%$ had Total Cholesterol/HDL ratio $>6$, and $41 \%$ had excess lipemia (Weiss et al, 1994).

The mortality of 1957 white male city of Buffalo firefighters employed for five or more years between the years of 1950 and 1988 were compared with US white male mortality (Wende, 1996). Unlike Glueck et al, (1996) and Weiss et al, (1984) risk of arteriosclerotic heart disease was neither elevated nor decreased significantly in firefighters as compared to the general population. However, a statistically significant trend of higher risk was found with increasing duration of employment whereas lower risk was found in more recent hires (Wende, 1996).

Increased risk of ischemic heart disease has been found in occupations that do not work 'day-work' only and have psychologically demanding work but unsatisfactory decision authority, such as police officers, naval officers and others (Tuchsen et al, 1996). Firefighters are often exposed to similar occupational challenges. The self-reported incidence of CVD and CVD risk factors in 232 male retirees $>55$ years of age, from the Iowa Department of Public Safety were compared with 817 male Iowans of similar age. Incidence of CVD was higher in law enforcement officers than the general population. Results suggested that employment as a law enforcement officer is associated with an increased CVD morbidity and this relationship persists after considering several conventional risk factors (Franke et al, 1998). 
Firefighters may also be at higher risk for CVD because of their diets. New York City firefighters lacked nutrition knowledge about differences between various kinds of dietary fats and calories contained in various foods, and lacked skills to distinguish the fat content of certain desserts, vegetables, and main meals (Locastro, 1989). When firefighters were classified according to their demographic characteristics, it was suggested that these findings may be extrapolated to the entire New York State firefighter population (Locastro, 1989).

In one fire station, it was found that biscuit pizza, tuna casserole, beef and corn pie, and chicken and noodle casserole were frequent meals for firefighters; recipes and nutrition guides were not generally consulted for meal preparation (Blankenship and Hagan, 1986). Accordingly, their diets have been found to be high in total fat, saturated fat, cholesterol, and sodium (Weiss et al, 1984). Logically, it may also be low in fruits and vegetables, which are major sources of folate. The present study examined variations of folate intake, folate food sources, and diet by age, gender, and ethnicity in Metro-Dade Firefighters and also determined the prevalence of obesity, physical inactivity and history heart disease. 


\section{CHAPTER III}

\section{METHODOLOGY}

Study Design

This study was conducted in 2000 and used a survey design, randomized by all fire station numbers in Metro-Dade County. Firefighters from randomly selected fire stations who volunteered to participate in the study completed a food-frequency questionnaire and a socio-demographic questionnaire.

\section{Study Population / Subject Selection}

The chief of the Metro-Dade County Fire Rescue Department provided a list of all 55 fire stations from which 15 fire stations were randomly chosen. Metro-Dade Fire Rescue workers are trained in both firefighting and emergency medical services. Hence, the term "firefighters" is also applied to fire station paramedics. Visits to the fire stations were made in order of the randomization. Work shifts were arbitrarily selected. MetroDade Firefighters are permanently assigned to a certain work shift, A, B or C for the year. Therefore, depending what day the researcher visited the fire station determined which shift, A, B, or C participated in the study. A total of 24 visits were made to fire stations in Metro-Dade County. Subjects were male and female Metro-Dade Firefighters of all ethnic groups who worked in the randomly selected fire stations. Metro-Dade Firefighters who volunteered from the chosen fire stations participated in the study. At the time of this study, the Metro-Dade Fire department consisted of approximately 1,500 firefighters.

The researcher visited the randomly selected fire stations, explained the study, and informed the firefighters that the questionnaires would require approximately 45 minutes to complete. The Metro-Dade Firefighters were informed that should they be 
interrupted by an emergency call, they would continue when they returned. Metro-Dade Firefighters interested in participating signed an informed consent form (Appendix A) approved by the FIU Institutional Review Board (IRB).

Sample Size

Using the power analysis for two sample testing (age and gender) for folate intake, with an alpha $=0.05$ and a power of $80 \%$ or more, the total sample size needed to be at least 126 to show a "medium effect" size $(\mathrm{d}=0.25)$ (Cohen, 1988). The effect size was determined by taking the difference between the mean for folate intake without supplements and mean for folate intake with supplements $(143 \mathrm{mcg})$ and dividing it by the standard deviation, which gave a medium effect of 0.25 . However, it was expected that some of the questionnaires may not be usable, therefore, a larger sample size $(\mathrm{n}=154)$ was used.

\section{Instrument Validation}

To assess the dietary intakes of Metro-Dade Firefighters, three instruments were considered: food-frequency questionnaire, diet records, and 24-hour recall. After examining the methods of several studies (Subar et al, 1989, Verhoef et al, 1998, Tucker, 1996, Oshaug et al, 1998, Brussard et al, 1997, Nygard et al, 1995, Pancharuniti et al, 1994, Willett et al, 1987), the Willett et al, (1985) food-frequency questionnaire was chosen because data indicated that a self-administered dietary questionnaire can provide useful information about individual nutrient intakes over a one-year period. The Willett et al, (1985) food-frequency questionnaire has been validated as an instrument to assess dietary intake as well as folate intake (Willet et al, 1985, Tucker et al, 1996, Jacques, et al, 1993). Since it has been shown to resemble diet records for several nutrients (Willett 
et al, 1987), collecting diet records from Metro-Dade Firefighters appeared to be unnecessary.

Collecting 24-hour recalls was ineffective for two important reasons. First, they are valid for estimating the intake of groups but not for individual food intake (Block, 1982). Second, firefighters work for 24 hours then are off 48 hours. The reliability of the recall would be affected because it would be dependent on the day they were interviewed. Food habits are probably different at the fire station than at home. Therefore, the Willet et al, (1985) food-frequency questionnaire was used because it assesses individual nutrient intakes over a one-year period.

Consent Form

Approval for this study was obtained from the Florida International University Institutional Review Board (IRB) for the protection of human subjects. Subjects interested in participating in the study signed the consent form and received their own copy (Appendix A).

Pilot Study

To assure reliability of the socio-demographic questionnaire, a pilot study was conducted consisting of 15 males chosen from the Florida International University Campus Police Department. They were given the socio-demographic questionnaire and asked if the questions were clear and understandable. Revisions were made to make any adjustments needed to clarify the socio-demographic questionnaire.

Socio-Demographic Data

Subjects completed the socio-demographic personal questionnaire (Appendix B) that was developed for this study by the investigators. Questions addressed age, gender, 
ethnicity, educational level, length of time living in the United States, and duration of employment as a firefighter.

\section{Anthropometric Data}

Height and weight data were collected from each subject at the fire stations and recorded on the BMI form (Appendix C). The researcher weighed and measured height on calibrated scales, which were located in the gym of each fire station. BMI was calculated according to the following formula: $\mathrm{BMI}=\underline{\text { Weight }(\mathrm{kg})}$

$$
\text { Height }\left(\mathrm{m}^{2}\right)
$$

\section{Dietary Intake}

Subjects completed the Food-frequency Questionnaire adapted from the 1980 Nurses' Health Study Dietary Questionnaire (Willett et al, 1985). A total of 203 food items, with commonly used portion sizes and methods of preparation are listed in eight categories by frequency of food consumption during the past year. Dietary intakes of fat, carbohydrates, protein, folate, fruits, vegetables, breakfast cereals, and intakes of alcohol and vitamins were calculated by Harvard Nutrient Database Systems. Data was compared with the 2000-2001 Dietary Reference Intakes (DRI) for adult men and women as well as the CSFII. Firefighters were classified into two age groups, younger (25-39 yrs) and older (40-58 yrs). This made it possible to make comparisons to established US data.

\section{CVD Risk Factors}

After taking the American Heart Association Cardiac Risk Evaluation Questionnaire (CREQ) and current literature into account, CVD risk factors were classified into three categories: major non-modifiable, major modifiable, and additional 
contributing risk factors. The CVD risk factors that were investigated in this study were: major non-modifiable - age ( $>65$ years), gender (male), ethnicity (African-American), familial and self history of heart disease; major modifiable - smoking, high blood pressure, physical inactivity, obesity and overweight (high BMI) and diabetes; additional contributing risk factors - total fat intake ( $>30 \%$ of calories), saturated fat intake ( $>$ $10 \%$ of calories), dietary cholesterol ( $>300 \mathrm{mg})$ and folate intake $(<400 \mathrm{mcg})$.

Responses to the socio-demographic questionnaire and intakes from the Willet FFQ determined the number of risk factors. An increased number of these risk factors indicated a higher risk for CVD.

Data Analysis

\begin{tabular}{|c|c|c|}
\hline $\begin{array}{c}\text { MAJOR NON- } \\
\text { MODIFIABLE CVD } \\
\text { RISK FACTOR } \\
\text { VARIABLES }\end{array}$ & $\begin{array}{c}\text { WHAT WAS MEASURED \& } \\
\text { HOW }\end{array}$ & ANALYSIS \\
\hline Age & $\begin{array}{l}\text { Self-reported years of age } \\
\text { Socio-Demographic } \\
\text { Questionnaire }\end{array}$ & $\begin{array}{l}\text { Mean, median of sample, by } \\
\text { gender and ethnicity. Two } \\
\text { sample t-tests and ANOVA } \\
\text { on folate intake measured } \\
\text { differences by age. }\end{array}$ \\
\hline Gender & $\begin{array}{l}\text { Male, Female } \\
\text { Socio-Demographic } \\
\text { Questionnaire }\end{array}$ & $\begin{array}{l}\text { Mean, median of sample by } \\
\text { gender and ethnicity. Two } \\
\text { sample t-tests and ANOVA } \\
\text { on folate intake measured } \\
\text { differences by gender. }\end{array}$ \\
\hline Ethnicity & $\begin{array}{l}\text { Non-Hispanic white, Hispanic, } \\
\text { non-Hispanic black, Other } \\
\text { Socio-Demographic } \\
\text { Questionnaire }\end{array}$ & $\begin{array}{l}\text { Frequency }(\mathrm{n}) \text { within } \\
\text { Category, } \% \text { of sample and } \\
\text { by gender. }\end{array}$ \\
\hline
\end{tabular}




\begin{tabular}{|c|c|c|}
\hline $\begin{array}{l}\text { Family and Self } \\
\text { History of Heart } \\
\text { Disease }\end{array}$ & $\begin{array}{l}\text { Categories: } 1-3 \text { relatives with } \\
\text { HD }<60 \text { yrs, } 0-3 \text { relatives with } \\
\text { HD }>60 \text { yrs, none, not known. } \\
\text { Socio-Demographic } \\
\text { Questionnaire. }\end{array}$ & $\begin{array}{l}\text { Frequency (n) within } \\
\text { Category; \% of sample. }\end{array}$ \\
\hline $\begin{array}{c}\text { MAJOR } \\
\text { MODIFIABLE CVD } \\
\text { RISK FACTOR } \\
\text { VARIABLES }\end{array}$ & $\begin{array}{c}\text { WHAT WAS MEASURED \& } \\
\text { HOW }\end{array}$ & ANALYSIS \\
\hline Smoking Habits & $\begin{array}{l}\text { Categories: never smokers, } \\
\text { former smokers, light smokers, } \\
\text { and heavy smokers. } \\
\text { Socio-Demographic } \\
\text { Questionnaire }\end{array}$ & $\begin{array}{l}\text { Frequency (n) within } \\
\text { Category; \% of sample. }\end{array}$ \\
\hline Physical Activity & $\begin{array}{l}\text { Categories:1)sedentary or no } \\
\text { activity; } 2 \text { )walking, cycling, or } \\
\text { other type of moderate } \\
\text { physical activity for at least } 4 \\
\text { hr/wk (moderate activity); } 3 \text { ) } \\
\text { exercise, gardening with } \\
\text { physical activity or similar } \\
\text { degree of physical activity for } \\
\text { at least } 4 \text { hr/wk (active } \\
\text { exercise) 4) regular heavy } \\
\text { training or competitive sport } \\
\text { several times/wk (heavy } \\
\text { training) } \\
\text { Socio-Demographic } \\
\text { Questionnaire }\end{array}$ & $\begin{array}{l}\text { Frequency (n) within } \\
\text { Category; \% of sample. }\end{array}$ \\
\hline BMI & $\begin{array}{l}\text { BMI: WT }(\mathrm{kg}) / \mathrm{HT}\left(\mathrm{m}^{2}\right) \\
\text { Underweight: } \mathrm{BMI}<19 \\
\text { Healthy: } \mathrm{BMI}=19-24.9 \\
\text { Overweight } \mathrm{BMI} \geq 25 \\
\text { Obese: } \mathrm{BM} \geq 30 \\
\text { BMI Form }\end{array}$ & $\begin{array}{l}\text { Mean, median, \% BMI } \\
\text { categories of sample and by } \\
\text { age, gender, ethnicity. Two } \\
\text { sample t-test by age. Chi- } \\
\text { Square on \% of sample } \\
\text { among gender and ethnic } \\
\text { groups. }\end{array}$ \\
\hline
\end{tabular}




\begin{tabular}{|c|c|c|}
\hline $\begin{array}{c}\text { ADDITIONAL } \\
\text { CONTRIBUTING } \\
\text { MODIFIABLE CVD } \\
\text { RISK FACTOR } \\
\text { VARIABLES }\end{array}$ & $\begin{array}{c}\text { WHAT WAS MEASURED \& } \\
\text { HOW }\end{array}$ & ANALYSIS \\
\hline Fat Intake & $\begin{array}{l}\text { Total Fat, Saturated Fat intake, } \\
\text { and Cholesterol intake. } \\
\text { Elevated: }>30 \% \text { Total Fat; } \\
>10 \% \text { Sat. Fat, >300mg chol. } \\
\text { Willett Food-Frequency }\end{array}$ & $\begin{array}{l}\text { Harvard Database: } \\
\text { Mean, median, \% elevated } \\
\text { of sample and by age and } \\
\text { gender. Two sample t-tests } \\
\text { by age. }\end{array}$ \\
\hline Folate Intake & $\begin{array}{l}\text { Folate intake }(\mathrm{mcg} / \mathrm{d}) \\
\leq 50 \% \text { of DRI } \\
\leq 75 \% \text { of DRI } \\
\leq 100 \% \text { of DRI } \\
\text { Willett Food-Frequency }\end{array}$ & $\begin{array}{l}\text { Harvard Database: } \\
\text { Mean, median, folate } \\
\text { density of sample and by } \\
\text { age, ethnicity, gender; } \\
\text { Compare with DRI, CSFII; } \\
\text { Two sample t-tests and } \\
\text { ANOVA on dietary folate } \\
\text { intake measured differences } \\
\text { by age. Chi-Square on \% of } \\
\text { sample among age, gender, } \\
\text { and ethnic groups }\end{array}$ \\
\hline OTHER VARIABLES & $\begin{array}{c}\text { WHAT WAS MEASURED \& } \\
\text { HOW }\end{array}$ & ANALYSIS \\
\hline Employment & $\begin{array}{l}\text { Duration as a firefighter } \\
\text { reported in years. } \\
\text { Socio-Demographic } \\
\text { Questionnaire }\end{array}$ & $\begin{array}{l}\text { Mean, median of sample } \\
\text { and by age, gender and } \\
\text { ethnicity. }\end{array}$ \\
\hline Education & $\begin{array}{l}\text { Categories: Some High } \\
\text { School, Completed High } \\
\text { School, Some College, } \\
\text { Completed College, Post-Grad } \\
\text { Socio-Demographic } \\
\text { Questionnaire }\end{array}$ & $\begin{array}{l}\text { Frequency (n) within } \\
\text { Category; \% of sample by } \\
\text { age, gender, and ethnicity. }\end{array}$ \\
\hline Diet & $\begin{array}{l}\text { Number and percent of kcal } \\
\text { from fat, protein, } \\
\text { carbohydrates } \\
\text { Willett Food-Frequency }\end{array}$ & $\begin{array}{l}\text { Harvard Database: Mean, } \\
\text { median, \% kcal fat, protein, } \\
\text { CHO of sample and by age. } \\
\text { Two sample t-tests by age. }\end{array}$ \\
\hline
\end{tabular}




\begin{tabular}{|l|l|l|}
\hline Vitamin Use & $\begin{array}{l}\text { Multi-vitamin intake } \\
\text { Folic Acid supplement intake } \\
\text { Willett Food-Frequency }\end{array}$ & $\begin{array}{l}\text { Harvard Database: } \\
\text { Mean, median of sample. }\end{array}$ \\
\hline $\begin{array}{l}\text { Folate Sources } \\
\text { (predominant) }\end{array}$ & $\begin{array}{l}\text { Dietary folate sources (mcg) } \\
\text { contrib. to total folate intake. }\end{array}$ & $\begin{array}{l}\text { Harvard Database: } \\
\% \text { of total dietary folate } \\
\text { intake of sample. }\end{array}$ \\
\hline $\begin{array}{l}\text { Food Guide Pyramid } \\
\text { Food Groups: Grain, } \\
\text { Fruit, Vegetables, } \\
\text { Dairy, Meat, and Tip. }\end{array}$ & Servings per day & $\begin{array}{l}\text { Mean, median, of sample } \\
\text { and by age and gender; } \\
\text { Compare with DRI, CSFII } \\
\text { by age and gender. }\end{array}$ \\
\hline
\end{tabular}

Statistical Analysis

Descriptive analysis (mean, median, standard deviation, frequency distribution) was used to analyze socio-demographic, anthropometric and dietary intake data. Two sample t-tests and one way analyses of variance on: Food Guide Pyramid food group servings, calorie, macronutrient, micronutrient, and folate intake were performed to measure differences by age and gender. Chi-square tests on BMI and folate intake categories were performed to measure differences for each gender separately. 


\section{RESULTS}

\section{Sample Characteristics}

Table 1 shows the characteristics of the 15 fire stations that were randomly selected from all 55 Fire Stations in Metro-Dade County. Metro-Dade Firefighters are permanently assigned to a certain shif, $\mathrm{A}, \mathrm{B}$ or $\mathrm{C}$ for the year. Depending on the day of the visit that was made to the fire station determined which shift, $\mathrm{A}, \mathrm{B}$, or $\mathrm{C}$ participated in the study. A total of 24 visits were made to fire stations in Metro-Dade County. Of the 154 firefighters that were asked to participate in the study, 132 volunteered. One hundred and twenty-seven $(86 \%)$ were included in the nutritional analysis. Five subjects were excluded due to: missing questionnaires due to emergency calls $(n=3)$ and incomplete FFQ $(n=2)$.

The gender and ethnic distribution of the Metro-Dade Firefighters is presented in Table 2. Eighty-three and one-half percent of the Metro-Dade Firefighters were males $(n=106)$ and $16.5 \%$ were females, $(n=21)$. The racial ethnic status of the 127 Metro-Dade Firefighters were: 74 white (58.3\%) 32 Hispanic (25.2\%), 18 African American (14.2\%) and 3 from other ethnic groups (2.4\%). Of the 106 males, $57.6 \%$ were white, $25.5 \%$ were Hispanic, and $15.1 \%$ were African-American. Of the 21 females, $61.9 \%$ were white, $23.8 \%$ were Hispanic, and $9.5 \%$ were African-American.

The mean and SD for age of the Metro-Dade Firefighters was 39.1 \pm 9.0 years. The mean years of employment as a firefighter was $12.4 \pm 8.8$. The highest educational level attained by Metro-Dade Firefighters is presented in Table 3. Seventy-six percent $(n=97)$ of the Metro-Dade Firefighters have attained less than a bachelor degree, whereas $24 \%$ have earned a bachelor degree or more. The distribution of educational level for men 
Table 1

Randomization Fire Stations

Visit No. Fire Station No.* Shift No. Offered No. Volunteered

\begin{tabular}{|c|c|c|c|c|}
\hline 1 & 74 & C & 7 & 7 \\
\hline 2 & 72 & C & 8 & 8 \\
\hline 3 & 74 & A & 8 & 8 \\
\hline 4 & 113 & C & 7 & 6 \\
\hline 5 & 118 & B & 7 & 6 \\
\hline 6 & 99 & C & 7 & 4 \\
\hline 7 & 118 & C & 7 & 6 \\
\hline 8 & 117 & $A$ & 6 & 4 \\
\hline 9 & 114 & $A$ & 7 & 7 \\
\hline 10 & 118 & A & 7 & 6 \\
\hline 11 & 99 & B & 4 & 2 \\
\hline 12 & 117 & B & 7 & 6 \\
\hline 13 & 91 & $C$ & 7 & 6 \\
\hline 14 & 75 & $C$ & 8 & 7 \\
\hline 15 & 117 & $C$ & 4 & 3 \\
\hline 16 & 106 & $C$ & 7 & 6 \\
\hline 17 & 73 & B & 7 & 6 \\
\hline 18 & 101 & B & 3 & 3 \\
\hline 19 & 106 & B & 7 & 4 \\
\hline 20 & 91 & B & 7 & 6 \\
\hline 21 & 74 & B & 7 & 6 \\
\hline 22 & 114 & B & 4 & 4 \\
\hline 23 & 113 & B & 4 & 4 \\
\hline 24 & 72 & $B$ & 7 & 7 \\
\hline Total & & & 154 & 132 \\
\hline
\end{tabular}

Excluded:

Missing Due to Emergency Calls 3

Incomplete 2

Total Sample Size

127

* Fire Station numbers have been arbitrarily changed to maintain confidentiality. 


\begin{tabular}{|c|c|c|c|c|c|c|}
\hline \multirow{2}{*}{ Ethnicity } & \multicolumn{2}{|c|}{ Total } & \multicolumn{2}{|c|}{$\operatorname{Men}(n=106)$} & \multicolumn{2}{|c|}{ Women $(n=21)$} \\
\hline & $\mathbf{n}$ & $\%$ & $\mathbf{n}$ & $\%$ & $\mathbf{n}$ & $\%$ \\
\hline White & 74 & 58.3 & 61 & 57.5 & 13 & 61.9 \\
\hline Hispanic & 32 & 25.2 & 27 & 25.5 & 5 & 23.8 \\
\hline African-American & 18 & 14.2 & 16 & 15.1 & 2 & 9.5 \\
\hline Other & 3 & 2.4 & 2 & 1.9 & 1 & 4.8 \\
\hline Total & 127 & 100.0 & 106 & 83.5 & 21 & 16.5 \\
\hline
\end{tabular}

Table 3

Highest Education Level Attained by Metro-Dade Firefighters ( $n=127)$

\begin{tabular}{lrr}
\hline Education Level & $\mathbf{n}$ & $\%$ \\
\hline Less than a Bachelor Degree & & \\
$\quad$ Men & 97 & 76 \\
Women & 16 & 76 \\
& & \\
& & \\
Bachelor Degree or more & 30 & 24 \\
$\quad$ Men & 25 & 24 \\
$\quad$ Women & 5 & 24 \\
\hline
\end{tabular}


$(n=106)$ and women $(n=21)$ was the same, $76 \%$ for less than a bachelor degree and $24 \%$ for bachelors degree or more.

The length of time of Metro-Dade Firefighters living in US is presented in Table 4. The majority of the Metro-Dade Firefighters, $n=110(86.6 \%)$, have lived in the US all of their lives. None of them have lived here less than 4 years. Only one $(0.8 \%)$ has lived in the US 4 to 5 years while $16(12.6 \%)$ have lived in the US for more than 5 years. $B M I$

Not presented in a table, the mean and SD for height and weight for Metro-Dade Firefighters were $68.9 \pm 2.9$ and $190.8 \pm 31.8$ respectively. The mean body mass index (BMI) for the Metro-Dade Firefighters was $28.2 \pm 3.6$. After placing the Metro-Dade Firefighters into two major age groups, $25-39$ yrs $(n=70)$ and $40-58$ yrs $(n=57)$, the mean BMIs were $27.9 \pm 3.8$ and $28.6 \pm 3.4$ respectively. The slight increase in BMI with age was not statistically significant.

The gender and ethnic distribution of BMI in Metro-Dade Firefighters is presented in Table 5. According to the Center for Disease Control (CDC) classification system, approximately $78 \%(n=99)$ of Metro-Dade Firefighters would be classified as overweight or obese. Although none of them were underweight or morbidly obese, only $22 \%(n=28)$ of the total population of Metro-Dade Firefighters were of acceptable weight.

There was a significant difference in the BMI distribution by ethnicity of MetroDade Firefighters, $X^{2}(2, n=127)=14.597, p<.001$. Significantly $(p<.001)$ more whites were of acceptable weight (29.7\%) and overweight (52.7\%) than non-whites, $11.3 \%$ and $41.5 \%$ respectively. However, significantly $(\mathrm{p}<.001)$ more non-whites $(47.2 \%)$ than 
Table 4

Length of Time of Metro-Dade Firefighters Living in the US $(n=127)$

\begin{tabular}{lrr} 
Length of Time & $\mathbf{n}$ & $\%$ \\
\hline 4 - 5 years & 1 & 0.8 \\
More than 5 years & 16 & 12.6 \\
All of my life & 110 & 86.6 \\
\hline
\end{tabular}

\section{Table 5}

Body Mass Index ${ }^{a}(B M I)$ by Gender and Ethnicity, Metro-Dade Firefighters ( $\left.n=127\right)$

\begin{tabular}{|c|c|c|c|c|c|c|}
\hline \multirow{2}{*}{ BMI $^{\mathrm{b}}$} & \multicolumn{2}{|c|}{ Total $(n=127)$} & \multicolumn{2}{|c|}{ White $(n=74)$} & \multicolumn{2}{|c|}{ Non-White $(\mathrm{n}=\mathrm{s}$} \\
\hline & $\mathbf{n}$ & $\%$ & $\mathbf{n}$ & $\%$ & $\mathbf{n}$ & $\%$ \\
\hline Underweight (<18.5) & ---- & ---- & ---- & ---- & ---- & ----- \\
\hline Acceptable Weight (18.5-24.9) & 28 & 22.0 & 22 & $29.7^{\star}$ & 6 & $11.3^{*}$ \\
\hline Men $(n=106)$ & 15 & 14.2 & 13 & 17.6 * & 2 & $3.8^{*}$ \\
\hline Women $(n=21)$ & 13 & 61.9 & 9 & 12.2 & 4 & 7.5 \\
\hline
\end{tabular}

Overweight (25.0-29.9)

$6148.0 \quad 3952.7^{*} \quad 22 \quad 41.5^{*}$

Men $(n=106)$

$5450.9 \quad 35 \quad 47.3^{*} \quad 19 \quad 35.8^{*}$

Women $(n=21)$

$7 \quad 33.3$

$4 \quad 5.4$

$3 \quad 5.7$

Obese (30.0-39.9)

$3829.91317 .6^{*}$

$2547.2^{\star}$

Men $(n=106)$

$37 \quad 34.9 \quad 13 \quad 17.6^{*}$

$2445.3^{*}$

Women $(n=21)$

14.8

1100.0

Morbidly Obese (>40.0)

${ }^{\circ}$ Classification as defined by the CDC.

${ }^{\mathrm{b}} \mathrm{BMI}=$ body mass index, defined as weight $(\mathrm{kg}) / \mathrm{ht}\left(\mathrm{m}^{2}\right)$.

*Significant difference in BMI distribution by ethnicity of Metro-Dade Firefighters, $\mathrm{X}^{2}(2$,

$\mathrm{n}=127)=14.597, \mathrm{p}<.001$ and by ethnicity of male FF, $X^{2}(2, n=106)=13.981, \mathrm{p}<.001$. 
whites $(17.6 \%)$ were obese. Overall non-whites were heavier than whites, $88.7 \%$ of nonwhites were either overweight or obese compared to $70.2 \%$ of whites. There also was a significant difference in the BMI distribution by ethnicity of male Metro-Dade Firefighters, $X^{2}(2, N=106)=13.981, p<.001$. Significantly more white men $(47.3 \%)$ than non-white men (35.8\%) were overweight. However, more non-white men (45.3\%) were obese than white men (17.6\%). (Table 5).

Although differences in BMIs between genders were not statistically significant, more men were heavier than women, Approximately $51 \%$ of the men and $33 \%$ of the women were overweight whereas $35 \%$ of the men and $4.8 \%$ of the women were obese. Of those that would be classified as acceptable weight, only $14.2 \%$ of the men fall into this category compared to $61.9 \%$ of women. (Table 5 ).

Dietary Analysis

The caloric and macronutrient intake of Metro-Dade Firefighters is presented in Table 6. Overall, the Metro-Dade Firefighters consumed an average of $1,950 \pm 904.3 \mathrm{kcal}$ per day, $46 \%$ of it coming from carbohydrates $(227 \pm 106 \mathrm{gm})$ and $18.5 \%$ coming from protein $(90 \pm 45 \mathrm{gm})$, which fall into the recommended ranges by the United States Department of Agriculture (USDA) Food Guide Pyramid (1600-2200 kcal, 55\% carbohydrate, $15 \%$ protein). The percentage of energy from both total fat and saturated fat $(32.0 \%, 10.4 \%)$ and consumption of dietary cholesterol $(316 \pm 183 \mathrm{mg})$ were higher than those recommended by the American Heart Association (AHA) and the USDA ( $<30 \%$ fat, $<10 \%$ saturated fat, $<300 \mathrm{mg}$ per day). There was a notable difference between the recommended intake of fiber by the AHA (25-30gm per day) and average intake of $17 \mathrm{gm} \pm 8.5$ by the Metro-Dade Firefighters. 
When comparing the caloric and macronutrient intake by age, protein intake was significantly higher $(\mathrm{p}<0.03)$ for younger than older Metro-Dade Firefighters (Table 7). The mean protein intake for the $25-39 \mathrm{yrs}$ age group was $98 \pm 53 \mathrm{gm}$, whereas for the $40-58$ yrs group it was $80 \pm 28 \mathrm{gm}$. Although not significant, intakes also decreased with increasing age for total energy, carbohydrates, and cholesterol. Total fat and saturated fat intakes were similar for both groups, approximately 70 and $23 \mathrm{gm}$ per day respectively.

The micronutrient intake of Metro-Dade Firefighters is presented in Table 8. The means for micronutrient intakes are based on dietary intake without supplements or with supplements and are compared to the dietary reference intakes (DRI), established by the National Research Council,1999-2001. Reported supplement intake by Metro-Dade Firefighters is presented in Table 9.

As shown in Table 8, with or without supplements, the Metro-Dade Firefighters intake fell below the DRI for calcium, $802 \pm 445 \mathrm{mg}$ and $683 \pm 397 \mathrm{mg}$; however, they met the DRIs for vitamin A, vitamin D, vitamin C, thiamin, riboflavin, vitamin B6, vitamin B12, iron, and zinc. The means for some of the micronutrients without supplements i.e. niacin, phosphorous, magnesium, iodine, and selenium were not available. However, when supplements were included, all of the DRIs were met except for selenium, which had a mean of $18.8 \pm 57.9 \mathrm{mcg}$ per day compared to the DRI of selenium of $55 \mathrm{mcg}$. Dietary intake of vitamin E, folate, and calcium were insufficient compared to the DRIs; however, when supplements were included, they all met the requirements except for calcium which was still insufficient. There were notable differences between supplementation levels and the DRIs for some of the micronutrients such as vitamin A, 


\begin{tabular}{|c|c|c|}
\hline Nutrients & Mean $\pm S D^{b}$ & $\begin{array}{c}\% \text { of Total } \\
\text { Energy }\end{array}$ \\
\hline Total Energy (kcal) & $1950 \pm 904.3$ & 100.0 \\
\hline Carbohydrates (gm) & $227 \pm 106.0$ & 46.6 \\
\hline Protein (gm) & $90 \pm 44.5$ & 18.5 \\
\hline Fat (gm) & $69 \pm 40.0$ & 32.3 \\
\hline Saturated Fat (gm) & $23 \pm 13.3$ & 10.4 \\
\hline Monounsaturated Fat (gm) & $27 \pm 15.6$ & 12.2 \\
\hline Polyunsaturated Fat (gm) & $14 \pm 9.9$ & 6.5 \\
\hline Cholesterol (mg) & $316 \pm 183.0$ & -------- \\
\hline Fiber (gm) & $17 \pm 8.5$ & 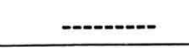 \\
\hline
\end{tabular}




\begin{tabular}{|c|c|c|c|}
\hline Nutrients & Age & $\mathbf{n}$ & Mean $\pm S D^{b}$ \\
\hline \multirow[t]{2}{*}{ Total Energy (kcal) } & $25-39$ & 70 & $2004 \pm 1048.9$ \\
\hline & $40-58$ & 57 & $1884 \pm 700.7$ \\
\hline \multirow[t]{2}{*}{ Carbohydrates (gm) } & $25-39$ & 70 & $231 \pm 117.3$ \\
\hline & $40-58$ & 57 & $223 \pm 92.1$ \\
\hline \multirow[t]{2}{*}{ Protein (gm) } & $25-39$ & 70 & $98 \pm 53.3^{\star}$ \\
\hline & $40-58$ & 57 & $80 \pm 28.3^{*}$ \\
\hline \multirow[t]{2}{*}{ Total Fat (gm) } & $25-39$ & 70 & $69 \pm 44.3$ \\
\hline & $40-58$ & 57 & $70 \pm 34.3$ \\
\hline \multirow[t]{2}{*}{ Saturated Fat (gm) } & $25-39$ & 70 & $23 \pm 15.2$ \\
\hline & $40-58$ & 57 & $22 \pm 10.7$ \\
\hline \multirow[t]{2}{*}{ Cholesterol (mg) } & $25-39$ & 70 & $337 \pm 215.8$ \\
\hline & $40-58$ & 57 & $291 \pm 131.8$ \\
\hline \multicolumn{4}{|c|}{ a Based on the Willet Food-frequency Questionnaire (Willett et al, 1985). } \\
\hline \multicolumn{4}{|c|}{$\begin{array}{l}{ }^{b} S D=S t a n d a r d \text { Deviation } \\
{ }^{\star} \mathrm{p}<0.03 \text {, difference among age groups determined by } t \text { test. }\end{array}$} \\
\hline
\end{tabular}




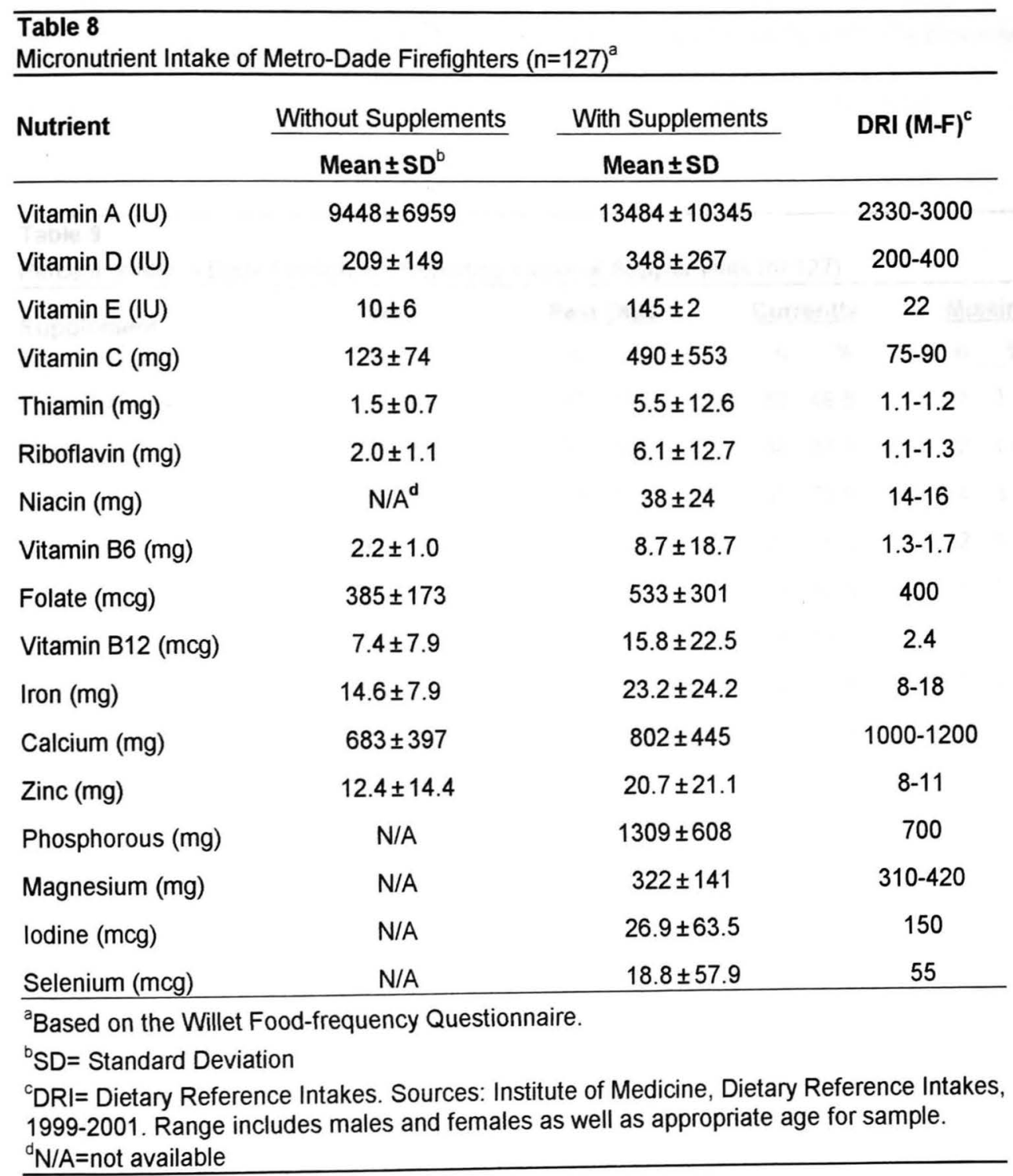




\begin{tabular}{|c|c|c|c|c|c|c|c|c|}
\hline \multirow{2}{*}{ Supplement } & \multicolumn{2}{|c|}{ Never } & \multicolumn{2}{|c|}{ Past Only } & \multicolumn{2}{|c|}{ Currently } & \multicolumn{2}{|c|}{ Missing } \\
\hline & $\mathbf{N}$ & $\%$ & $\mathbf{n}$ & $\%$ & $\mathbf{n}$ & $\%$ & $\mathrm{n}$ & $\%$ \\
\hline Multi-Vitamins & 18 & 14.2 & 42 & 33.1 & 63 & 49.6 & 4 & 3.1 \\
\hline Vitamin C & 27 & 21.3 & 50 & 39.4 & 48 & 37.7 & 2 & 1.6 \\
\hline Vitamin $\mathrm{E}$ & 59 & 46.5 & 34 & 26.8 & 30 & 23.6 & 4 & 3.1 \\
\hline Calcium & 91 & 71.7 & 13 & 10.2 & 21 & 16.5 & 2 & 1.6 \\
\hline Zinc & 81 & 63.7 & 26 & 20.5 & 17 & 13.4 & 3 & 2.4 \\
\hline Vitamin B6 & 90 & 70.9 & 19 & 15.0 & 14 & 11.0 & 4 & 3.1 \\
\hline Vitamin A & 80 & 63.0 & 29 & 22.9 & 12 & 9.4 & 6 & 4.7 \\
\hline Beta-Carotene & 96 & 75.6 & 17 & 13.4 & 12 & 9.4 & 2 & 1.6 \\
\hline Selenium & 102 & 80.2 & 11 & 8.7 & 11 & 8.7 & 3 & 2.4 \\
\hline Iron & 85 & 66.9 & 28 & 22.0 & 11 & 8.7 & 3 & 2.4 \\
\hline Omega 3 Fatty Acids & 97 & 76.4 & 21 & 16.5 & 6 & 4.7 & 3 & 2.4 \\
\hline
\end{tabular}


vitamin $\mathrm{C}$, vitamin $\mathrm{E}$, vitamin $\mathrm{B} 6$, thiamin, riboflavin, and vitamin $\mathrm{B} 12$, which were more than $500-600 \%$ of the DRI.

\section{Supplements}

Many of the aforementioned nutrients were also popular as supplements with Metro-Dade Firefighters, especially vitamin E and vitamin C, $38 \%$ and $24 \%$ followed by calcium and zinc, $17 \%$ and $14 \%$ respectively (Table 9 ). However, the most commonly used supplement was a multi-vitamin (50\%) which was also greater compared to those who have only taken it in the past $(34 \%)$ or have never taken it (14\%). A greater percentage of females $(71.4 \%)$ than males $(47.1 \%)$ reported currently taking multivitamins. More (58.2\%) older (age 40-58 years) Metro-Dade Firefighters than younger (age 25-39 years) Metro-Dade Firefighters (45.6\%) reported taking multivitamin supplements.

Past usage of vitamin C intake was common (39.4\%) whereas most selenium use was reported infrequently $(81 \%)$. The least popular supplement was omega 3 fatty acids with only $4.7 \%$ reporting current use.

Metro-Dade Firefighters were also able to write-in supplements that were not included in the questionnaire. The frequency of these supplements were: Metamucil 3.9\% $(n=5)$, vitamin D $0.8 \%(n=1)$, potassium $1.6 \%(n=2)$, magnesium $2.4 \%(n=3)$, folic acid $2.4 \%(n=3)$ and "others" $11.8 \%(n=18)$. The majority of the these supplements were taken by males.

\section{Folate Intake}

The only nutrient that comparisons within age groups were made for was folate. The mean intakes for folate without supplements and with supplements were similar 
within the two age groups, $25-39$ years, $398 \pm 190 \mathrm{mcg}, 40-58$ years, $369 \pm 149 \mathrm{mcg}$, and 25-39 years, $524 \pm 297 \mathrm{mcg}, 40-58$ years, $540 \pm 312 \mathrm{mcg}$ respectively. However, there was an approximately $148 \mathrm{mcg}$ increase in mean folate intake when supplements were included.

The comparison of the two age groups were looked into further in Table 10, which shows the percentage of individuals meeting the DRI for folate from food intake. There was no significant difference between the two age groups (25-39 years and 40-58 years) in the percentages of those meeting at least $100 \%$ of the DRI. However, more (36.8\%) from the older age group failed to meet $75 \%$ of the DRI, which is $300 \mathrm{mcg}$ of folate, compared to $25.7 \%$ of the younger age group. When supplement intakes were included (Table 11), folate intake improved. The percentage of those meeting at least $100 \%$ of the DRI increased to 57.1 and $57.9 \%$ or younger and older age groups respectively. Again, more (26.3\%) from the older age group failed to meet $75 \%$ of the DRI compared to $15.7 \%$ of the younger age group.

The percentage of individuals meeting the DRI for folate from food intake by gender is presented in Table 12. Unlike the age groups, there was a difference between the genders meeting the DRI. More males (40.6\%) met $100 \%$ of the DRI compared to females, $28.6 \%$. This disparity was also seen at $75 \%$ of the DRI, $72.6 \%$ for males and $52.4 \%$ for females meeting $75 \%$ of the DRI. However, when supplements were included, a greater percentage of females ( $85.7 \%$ and $71.4 \%)$ met $75 \%$ and $100 \%$ of the DRI than males, $78.3 \%$ and $54.7 \%$ respectively (Table 13 ). Overall, intake of folate for females improved more than males when supplement intakes were included than from food intake alone. The percentage of females meeting $100 \%$ of DRI increased from $28.6 \%$ to $71.4 \%$, 


\section{Table 10}

Percentage of Metro-Dade Firefighters Meeting the DRI for Folate ${ }^{a}$ from Food Intake, by Age $(n=127)$

\begin{tabular}{|c|c|c|c|c|c|c|}
\hline \multirow{2}{*}{ Percent of DRI } & \multicolumn{2}{|c|}{$25-39(n=70)$} & \multicolumn{2}{|c|}{$40-58(n=57)$} & \multicolumn{2}{|c|}{ Total } \\
\hline & $n$ & $\%$ & $n$ & $\%$ & $\mathbf{n}$ & $\%$ \\
\hline$<50 \%$ DRI & 5 & 7.1 & 5 & 8.8 & 10 & 7.9 \\
\hline $50 \%$ DRI & 65 & 92.9 & 52 & 91.2 & 117 & 92.1 \\
\hline$<75 \%$ DRI & 18 & 25.7 & 21 & 36.8 & 39 & 30.7 \\
\hline $75 \%$ DRI & 52 & 74.3 & 36 & 63.2 & 88 & 69.3 \\
\hline$<100 \%$ DRI & 42 & 60.0 & 36 & 63.2 & 78 & 61.4 \\
\hline $100 \%$ DRI & 28 & 40.0 & 21 & 36.8 & 49 & 38.6 \\
\hline
\end{tabular}

\begin{tabular}{|c|c|c|c|c|c|c|}
\hline $\begin{array}{l}\text { Table 11 } \\
\text { Percentage of Met } \\
\text { from Food and Su }\end{array}$ & $\begin{array}{l}\text { Dade } \\
\text { ement }\end{array}$ & $\begin{array}{l}\text { efighte } \\
\text { take, }\end{array}$ & $\begin{array}{l}\text { Meeting } \\
\text { Age }(n=\end{array}$ & $\begin{array}{l}\text { the DF } \\
\text { 27) }\end{array}$ & Folate & \\
\hline & $25-39$ & $=70)$ & $40-58$ & $(=57)$ & To & \\
\hline Percent of DRI & $n$ & $\%$ & $n$ & $\%$ & $\mathbf{n}$ & $\%$ \\
\hline$<50 \%$ DRI & 4 & 5.7 & 4 & 7 & 8 & 6.3 \\
\hline $50 \%$ DRI & 66 & 94.3 & 53 & 93 & 119 & 93.7 \\
\hline$<75 \%$ DRI & 11 & 15.7 & 15 & 26.3 & 26 & 20.5 \\
\hline $75 \%$ DRI & 59 & 84.3 & 42 & 73.7 & 101 & 79.5 \\
\hline$<100 \%$ DRI & 30 & 42.9 & 24 & 42.1 & 54 & 42.5 \\
\hline $100 \%$ DRI & 40 & 57.1 & 33 & 57.9 & 73 & 57.5 \\
\hline
\end{tabular}




\section{Table 12}

Percentage of Metro-Dade Firefighters Meeting the DRI for Folate ${ }^{a}$ from Food Intake, by Gender $(n=127)$

\begin{tabular}{|c|c|c|c|c|c|c|}
\hline \multirow{2}{*}{ Percent of DRI } & \multicolumn{2}{|c|}{ Male $(n=106)$} & \multicolumn{2}{|c|}{ Female $(n=21)$} & \multicolumn{2}{|c|}{ Total } \\
\hline & $\mathbf{n}$ & $\%$ & $\mathbf{n}$ & $\%$ & $\mathbf{n}$ & $\%$ \\
\hline$<50 \%$ DRI & 7 & 6.6 & 3 & 14.3 & 10 & 7.9 \\
\hline $50 \%$ DRI & 99 & 93.4 & 18 & 85.7 & 117 & 92.1 \\
\hline$<75 \%$ DRI & 29 & 27.4 & 10 & 47.6 & 39 & 30.7 \\
\hline $75 \%$ DRI & 77 & 72.6 & 11 & 52.4 & 88 & 69.3 \\
\hline$<100 \%$ DRI & 63 & 59.4 & 15 & 71.4 & 78 & 61.4 \\
\hline $100 \% \mathrm{DRI}$ & 43 & 40.6 & 6 & 28.6 & 49 & 38.6 \\
\hline
\end{tabular}

\section{Table 13}

Percentage of Metro-Dade Firefighters Meeting the DRI for Folate ${ }^{a}$ from Food and Supplement Intake, by Gender $(n=127)$

\begin{tabular}{|c|c|c|c|c|c|c|}
\hline \multirow{2}{*}{ Percent of DRI } & \multicolumn{2}{|c|}{ Male $(n=106)$} & \multicolumn{2}{|c|}{ Female $(n=21)$} & \multicolumn{2}{|c|}{ Total } \\
\hline & $\mathbf{n}$ & $\%$ & $n$ & $\%$ & $\mathbf{n}$ & $\%$ \\
\hline$<50 \%$ DRI & 6 & 5.7 & 2 & 9.5 & 8 & 6.3 \\
\hline $50 \%$ DRI & 100 & 94.3 & 19 & 90.5 & 119 & 93.7 \\
\hline$<75 \%$ DRI & 23 & 21.7 & 3 & 14.3 & 26 & 20.5 \\
\hline $75 \%$ DRI & 83 & 78.3 & 18 & 85.7 & 101 & 79.5 \\
\hline$<100 \%$ DRI & 48 & 45.3 & 6 & 28.6 & 54 & 42.5 \\
\hline $100 \%$ DRI & 58 & 54.7 & 15 & 71.4 & 73 & 57.5 \\
\hline
\end{tabular}


whereas males increased from $40.6 \%$ to $50.7 \%$.

Folate intake was also compared among three ethnic groups. Although more whites met $100 \%$ of the DRI for folate, the differences among the percentage of whites, Hispanics, and African-Americans meeting $100 \%$ of the DRI from food intake were not significant, $41.9 \%, 37.5 \%$, and $33.3 \%$ respectively (Table 14 ). However, a significantly greater $(p<0.05)$ percentage of African-Americans $(55.6 \%)$ failed to meet $75 \%$ of the DRI than whites (27\%) and Hispanics (25\%). A considerably smaller percentage of AfricanAmericans (72.2\%) met $50 \%$ of the DRI than whites (95.9\%) and Hispanics $(93.7 \%)$.

When supplements were included, the percentage of African-Americans failing to meet $75 \%$ of the DRI, was still significantly $(\mathrm{p}<0.03)$ more $(44.4 \%)$ than whites $(17.6 \%)$ and Hispanics (15.6\%) (Table 15). Although folate intake improved with supplement use among whites, Hispanics, and African-Americans, ethnic differences disappeared at $100 \%$ of the DRI, $58.1 \%, 56.3 \%$, and $55.6 \%$ respectively (Table 15 ). Overall, more whites met the DRI for folate from food or with the inclusion of supplements than the other ethnic groups at every category except at $75 \%$ of the DRI. Of the three ethnic groups, African-Americans had the lowest percentages of individuals meeting or failing to meet $50 \%, 75 \%$ and $100 \%$ of the DRI for folate from food or with the inclusion of supplements.

\section{Folate Sources}

Major contributors of food folate in the diet of Metro-Dade Firefighters are presented in Table 16. Liver (chicken or turkey) was the second biggest source, contributing $10.8 \%$ of dietary folate intake. However, the addition of pork and calf increased the contribution of total liver to $17 \%$. Grains, specifically white bread, white 


\section{Table 14}

Percentage of Metro-Dade Firefighters Meeting the DRI for Folate ${ }^{a}$ from Food Intake, by Ethnicity $(n=124)$

\begin{tabular}{|c|c|c|c|c|c|c|c|c|}
\hline \multirow[t]{2}{*}{ Percent of DRI } & \multicolumn{2}{|c|}{ White } & \multicolumn{2}{|c|}{ Hispanic } & \multicolumn{2}{|c|}{$\begin{array}{c}\text { African- } \\
\text { American }\end{array}$} & \multicolumn{2}{|c|}{ Total } \\
\hline & $\mathbf{n}$ & $\%$ & $\mathbf{n}$ & $\%$ & $\mathrm{n}$ & $\%$ & $\mathbf{n}$ & $\%$ \\
\hline$<50 \%$ DRI & 3 & 4.1 & 2 & 6.3 & 5 & 27.8 & 10 & 8.1 \\
\hline $50 \%$ DRI & 71 & 95.9 & 30 & 93.7 & 13 & 72.2 & 114 & 91.9 \\
\hline$<75 \% \mathrm{DRI}^{\star}$ & 20 & 27.0 & 8 & 25.0 & 10 & 55.6 & 38 & 30.6 \\
\hline $75 \% \mathrm{DRI}^{*}$ & 54 & 73.0 & 24 & 75.0 & 8 & 44.4 & 86 & 69.4 \\
\hline$<100 \%$ DRI & 43 & 58.1 & 20 & 62.5 & 12 & 66.7 & 75 & 60.5 \\
\hline $100 \%$ DRI & 31 & 41.9 & 12 & 37.5 & 6 & 33.3 & 49 & 39.5 \\
\hline
\end{tabular}

\section{Table 15}

Percentage of Metro-Dade Firefighters Meeting the DRI for Folate ${ }^{a}$ from Food and Supplement Intake, by Ethnicity $(n=124)$

\begin{tabular}{|c|c|c|c|c|c|c|c|c|}
\hline \multirow[t]{2}{*}{ Percent of DRI } & \multicolumn{2}{|c|}{ White } & \multicolumn{2}{|c|}{ Hispanic } & \multicolumn{2}{|c|}{$\begin{array}{l}\text { African- } \\
\text { American }\end{array}$} & \multicolumn{2}{|c|}{ Total } \\
\hline & $\mathbf{n}$ & $\%$ & $\mathrm{n}$ & $\%$ & $\mathrm{n}$ & $\%$ & $\mathrm{n}$ & $\%$ \\
\hline$<50 \%$ DRI & 1 & 1.4 & 2 & 6.3 & 5 & 27.8 & 8 & 6.5 \\
\hline $50 \%$ DRI & 73 & 98.6 & 30 & 93.7 & 13 & 72.2 & 116 & 93.5 \\
\hline$<75 \% \mathrm{DRI}^{*}$ & 13 & 17.6 & 5 & 15.6 & 8 & 44.4 & 26 & 21 \\
\hline $75 \% \mathrm{DRI}^{*}$ & 61 & 82.4 & 27 & 84.4 & 10 & 55.6 & 98 & 79 \\
\hline$<100 \%$ DRI & 31 & 41.9 & 14 & 43.7 & 8 & 44.4 & 53 & 42.7 \\
\hline $100 \%$ DRI & 43 & 58.1 & 18 & 56.3 & 10 & 55.6 & 71 & 57.3 \\
\hline
\end{tabular}


Table 16

Major Food Contributors of Folate in the Diet of Metro-Dade Firefighters.

\begin{tabular}{|c|c|c|c|c|c|c|}
\hline Rank & $\begin{array}{l}\text { Description of Folate } \\
\text { Sources }\end{array}$ & $\begin{array}{c}\text { Serving } \\
\text { Size }\end{array}$ & $\begin{array}{l}\text { Folate per } \\
\text { Serving } \\
\text { (mcg) }^{\mathrm{a}}\end{array}$ & 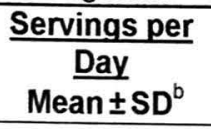 & $\begin{array}{l}\text { Total } \\
\text { Folate } \\
\text { (mcg) }\end{array}$ & $\begin{array}{c}\% \text { of } \\
\text { Total } \\
\text { Folate }\end{array}$ \\
\hline 1 & White Bread, Pita Bread ${ }^{c}$ & 1 slice & 40.0 & $2.74 \pm 3.41$ & 109.4 & 12.8 \\
\hline 2 & Liver: Chicken or Turkey & $1 \mathrm{oz}$. & 201.1 & $0.46 \pm 0.73$ & 91.9 & 10.8 \\
\hline 3 & Orange Juice & 1 cup & 109.0 & $0.63 \pm 0.73$ & 68.2 & 8.0 \\
\hline 4 & White Rice & 1 cup & 133.0 & $0.46 \pm 0.56$ & 61.6 & 7.2 \\
\hline 5 & Beans or Lentils & $1 / 2$ cup & 124.0 & $0.45 \pm 0.50$ & 55.3 & 6.5 \\
\hline 6 & Liver: Calf or Pork & $4 \mathrm{oz}$. & 216.8 & $0.25 \pm 0.40$ & 53.4 & 6.3 \\
\hline 7 & Romaine Lettuce & 1 cup & 76.0 & $0.64 \pm 0.70$ & 48.3 & 5.7 \\
\hline 8 & Dark Bread, Pita Bread & 1 slice & 13.4 & $3.25 \pm 4.36$ & 43.5 & 5.1 \\
\hline 9 & Cold Breakfast Cereal & 1 cup & 100.0 & $0.37 \pm 0.48$ & 36.6 & 4.3 \\
\hline 10 & Pasta: Spaghetti, Noodles & 1 cup & 60.0 & $0.55 \pm 0.49$ & 32.8 & 3.8 \\
\hline 11 & Spinach cooked & $1 / 2$ cup & 131.0 & $0.22 \pm 0.26$ & 29.3 & 3.4 \\
\hline 12 & Cooked Oatmeal/Oat Bran & 1 cup & 129.0 & $0.17 \pm 0.22$ & 21.6 & 2.5 \\
\hline 13 & Broccoli & $1 / 2$ cup & 39.0 & $0.53 \pm 0.55$ & 20.6 & 2.4 \\
\hline 14 & Tomato & 1 & 18.5 & $1.11 \pm 0.82$ & 20.5 & 2.4 \\
\hline 15 & Eggs, Whole with Yolk & 1 & 23.0 & $0.86 \pm 0.76$ & 19.7 & 2.3 \\
\hline 16 & Pizza & 2 slices & 88.0 & $0.20 \pm 0.25$ & 17.4 & 2.0 \\
\hline 17 & Spinach Raw & 1 cup & 58.2 & $0.29 \pm 0.41$ & 16.8 & 2.0 \\
\hline 18 & Bagels, English Muffin, Rolls & 1 whole & 58.5 & $0.26 \pm 0.31$ & 15.4 & 1.8 \\
\hline 19 & Pancake or Waffles & 3 pieces & 80.4 & $0.17 \pm 0.23$ & 13.6 & 1.6 \\
\hline 20 & Peanuts & $1 \mathrm{oz}$. & 41.1 & $0.21 \pm 0.47$ & 8.4 & 1.0 \\
\hline 21 & Other Cooked Brkfst Cereals & 1 cup & 75.0 & $0.11 \pm 0.18$ & 8.0 & 0.9 \\
\hline 22 & Orange & 1 & 44.0 & $0.17 \pm 0.22$ & 7.6 & 0.9 \\
\hline 23 & Tomato Sauce & $1 / 2$ cup & 11.0 & $0.51 \pm 0.47$ & 5.6 & 0.7 \\
\hline 24 & Tomato Juice & 1 cup & 48.6 & $0.11 \pm 0.17$ & 5.4 & 0.6 \\
\hline 25 & Dark Orange (winter) Squash & $1 / 2$ cup & 28.7 & $0.18 \pm 0.31$ & 5.1 & 0.6 \\
\hline 26 & Kale, Mustard, Greens & $1 / 2$ cup & 18.3 & $0.25 \pm 0.46$ & 4.6 & 0.5 \\
\hline 27 & French Fried Potatoes & $1 / 2$ cup & 11.8 & $0.39 \pm 0.38$ & 4.6 & 0.5 \\
\hline 28 & Muffins (regular) or Biscuit & 1 whole & 24.9 & $0.17 \pm 0.26$ & 4.3 & 0.5 \\
\hline 29 & Grapefruit Juice & 1 cup & 17.3 & $0.23 \pm 0.43$ & 3.9 & 0.5 \\
\hline 30 & Other Grains ie bulgur & 1 cup & 23.5 & $0.16 \pm 0.17$ & 3.8 & 0.4 \\
\hline 31 & Tortillas & 1 & 36.9 & $0.09 \pm 0.14$ & 3.4 & 0.4 \\
\hline 32 & Other Fruit Juice & 1 cup & 7.6 & $0.41 \pm 0.57$ & 3.1 & 0.4 \\
\hline 33 & Yams or Sweet Potatoes & $1 / 2$ cup & 10.9 & $0.23 \pm 0.31$ & 2.5 & 0.3 \\
\hline 34 & Peanut Butter & 1 tbs. & 11.8 & $0.20 \pm 0.31$ & 2.4 & 0.3 \\
\hline 35 & Crackers ie Triscuits, Thins & 5 & 13.8 & $0.12 \pm 0.17$ & 1.7 & 0.2 \\
\hline 36 & Grapefruit & $1 / 2$ & 14.8 & $0.12 \pm 0.18$ & 1.7 & 0.2 \\
\hline 37 & Cantaloupe & $1 / 4$ melon & 23.5 & $0.04 \pm 0.04$ & 0.9 & 0.1 \\
\hline 38 & Brown Rice & 1 cup & 3.9 & $0.24 \pm 0.38$ & 0.9 & 0.1 \\
\hline \multicolumn{7}{|c|}{$\begin{array}{l}\text { US Department of Agriculture, Agricultural Research Service. 2002. USDA National Nutrien } \\
\text { Database for Standard Reference, Release 15. Nutrient Data Laboratory Home Page, } \\
\text { http://www.nal.usda.gov/fnic/foodcomp. } \\
\text { 'SD=Standard of Deviation } \\
\text { If more than one food source is listed, the folate per serving was calculated by taking the } \\
\text { mean of the sources listed. }\end{array}$} \\
\hline
\end{tabular}


rice, dark bread, cold cereal, and pasta together contributed 34\%. Adding beans or lentils (6.5\%), increased the contribution to $40.5 \%$. Rich sources of folate such as orange juice, spinach, and broccoli were the top third, eleventh, and thirteenth contributors to folate intake. Not far behind, pizza ranked sixteenth.

\section{Food Guide Pyramid}

The mean numbers of Food Guide Pyramid servings compared by age groups of Metro-Dade Firefighters are presented in Table 17. There was a significant difference between the age groups for vegetable and meat intake. Older Metro-Dade Firefighters, 40-58 years, consumed significantly $(\mathrm{p}<0.05)$ more vegetables $(5.4 \pm 1.7$ servings $)$ than younger Metro-Dade Firefighters, 25-39 years, ( $4.8 \pm 1.9$ servings). However, younger Metro-Dade Firefighters consumed significantly $(\mathrm{p}<.05)$ more from the meat group than older firefighters, $7.3 \pm 5.0$ servings versus $5.8 \pm 2.6$ servings. There were no significant differences between age groups for servings from the grain, fruit, and dairy groups.

Metro-Dade Firefighter's pyramid servings per day were also compared by age and gender to the USDA Continuing Survey of Food Intake by Individuals (CSFII), 1994-1996,1998 (Tables 18-23). Intakes from the grain group for male Metro-Dade Firefighters were similar to data collected by the CSFII (Table 18); however, females consumed more servings. Approximately 59\% of female Metro-Dade Firefighters, 25-39 years, consumed the minimum number of servings per day of grains and $41.2 \%$ consumed the recommended number of servings based on caloric intake compared to $41 \%$ and $32-33 \%$ from CSFII, respectively. The percentage of male Metro-Dade Firefighters who consumed the minimum number of servings of grain based on caloric intake decreased with age but increased with age for female Metro-Dade Firefighters. 


\section{Table 17}

Mean numbers of Food Guide Pyramid ${ }^{a}$ Servings Consumed per Day, by Age, Metro-Dade Firefighters $(n=127)^{b}$

\begin{tabular}{cccc}
\hline Food Group & Age (yrs) & $\mathbf{n}$ & Mean $\pm \mathbf{S D}^{\mathbf{c}}$ \\
\hline Grain & $25-39$ & 70 & $9.7 \pm 6.6$ \\
& $40-58$ & 57 & $8.1 \pm 4.5$ \\
& $25-39$ & 70 & $4.8 \pm 1.9^{\star}$ \\
Vegetable & $40-58$ & 57 & $5.4 \pm 1.7^{\star}$ \\
& & & \\
Fruit & $25-39$ & 70 & $3.9 \pm 1.9$ \\
& $40-58$ & 57 & $4.1 \pm 1.9$ \\
Dairy & $25-39$ & 70 & $4.2 \pm 3.7$ \\
& $40-58$ & 57 & $4.5 \pm 3.2$ \\
& $25-39$ & 70 & $7.3 \pm 5.0^{*}$ \\
Meat & $40-58$ & 57 & $5.8 \pm 2.7^{\star}$ \\
\hline
\end{tabular}

${ }^{a}$ Food Guide Pyramid: A Guide to Daily Food Choices. Washington, DC: US Dept of Agriculture, Human Nutrition Information Service; 2000.

Home and Garden Bulletin No. 252.

${ }^{\mathrm{b}}$ Based on the Willet Food-frequency Questionnaire. (Willett et al, 1985).

${ }^{\circ} \mathrm{SD}=$ Standard Deviation

${ }^{*} p<0.05$, difference between age groups determined by $t$ test. 


\section{Table 18}

Grain: Percentage of Individuals Consuming Specified Numbers of Pyramid ${ }^{\text {a }}$ Servings per Day, by Gender and Age, Metro-Dade Firefighters and USDA Continuing Survey of Food Intake by Individuals, 1994-96, $98^{\circ}$

\begin{tabular}{|c|c|c|c|c|c|c|c|}
\hline \multicolumn{4}{|c|}{ Metro-Dade Firefighters } & \multicolumn{4}{|c|}{ USDA CSFII 1994-96, 98} \\
\hline $\begin{array}{c}\text { Gender } \\
\text { and Age } \\
\text { (yrs) }\end{array}$ & $\begin{array}{c}\text { Consuming } \\
<1 \text { serving } \\
\text { a day }\end{array}$ & $\begin{array}{l}\text { Consuming } \\
\text { minimum number } \\
\text { of servings } \\
\text { recommended } \\
\text { ( } 6 \text { a day) }\end{array}$ & $\begin{array}{c}\text { Consuming no. } \\
\text { of servings } \\
\text { recommended } \\
\text { based on caloric } \\
\text { intake }\end{array}$ & $\begin{array}{c}\text { Gender } \\
\text { and Age } \\
\text { (yrs) }\end{array}$ & $\begin{array}{c}\text { Consuming } \\
<1 \text { serving } \\
\text { a day }\end{array}$ & $\begin{array}{l}\text { Consuming } \\
\text { minimum number } \\
\text { of servings } \\
\text { recommended } \\
\text { (6 a day) }\end{array}$ & $\begin{array}{c}\text { Consuming no. } \\
\text { of servings } \\
\text { recommended } \\
\text { based on caloric } \\
\text { intake }\end{array}$ \\
\hline \multicolumn{4}{|c|}{ - } & \multicolumn{4}{|c|}{-__ Percent - } \\
\hline $\cos$ & & 10.0 & $4=1$ & $30-39$ & $<.05$ & 70 & 41 \\
\hline \multirow{2}{*}{$40-58$} & \multirow{2}{*}{----} & \multirow{2}{*}{69.8} & \multirow{2}{*}{43.4} & $40-49$ & 1 & 68 & 40 \\
\hline & & & & $50-59$ & 0 & 59 & 36 \\
\hline Total & --- & 71.7 & 46.2 & Total $^{c}$ & 1 & 37 & 41 \\
\hline \multirow{2}{*}{$40-58$} & \multirow{2}{*}{--} & \multirow{2}{*}{50.0} & \multirow{2}{*}{50.0} & $40-49$ & 1 & 39 & 33 \\
\hline & & & & $50-59$ & 1 & 37 & 31 \\
\hline Total & 4.8 & 57.1 & 42.9 & Total & 1 & 37 & 38 \\
\hline
\end{tabular}

${ }^{a}$ Food Guide Pyramid: A Guide to Daily Food Choices. Washington, DC: US Dept of Agriculture, Human Nutrition Information Service; 2000. Home and Garden Bulletin No. 252.

bUSDA/ARS (US Department of Agriculture, Agriculture Research Service). 2000b. Pyramid Servings Intakes by Children and Adults: 1994-96, 1998. Online. ARS Community Nutrition Research Group Web site, available at: http://www.barc.usda.gov/bhnrc/cnrg/

${ }^{c}$ Results given for total includes ages 20 and over. 


\section{Table 19}

Vegetables: Percentage of Individuals Consuming Specified Numbers of Pyramid ${ }^{a}$ Servings per Day, by Gender and Age, Metro-Dade Firefighters and USDA Continuing Survey of Food Intake by Individuals, 1994-96, 98

\begin{tabular}{|c|c|c|c|c|c|c|c|}
\hline \multicolumn{4}{|c|}{ Metro-Dade Firefighters } & \multicolumn{4}{|c|}{ USDA CSFII 1994-96, 98} \\
\hline $\begin{array}{c}\text { Gender } \\
\text { and Age } \\
\text { (yrs) }\end{array}$ & $\begin{array}{c}\text { Consuming } \\
<1 \text { serving } \\
\text { a day }\end{array}$ & \begin{tabular}{|c|} 
Consuming \\
minimum number \\
of servings \\
recommended \\
( 3 a day)
\end{tabular} & $\begin{array}{c}\text { Consuming no. } \\
\text { of servings } \\
\text { recommended } \\
\text { based on caloric } \\
\text { intake }\end{array}$ & $\begin{array}{c}\text { Gender } \\
\text { and Age } \\
\text { (yrs) }\end{array}$ & $\begin{array}{c}\text { Consuming } \\
<1 \text { serving } \\
\text { a day }\end{array}$ & $\begin{array}{c}\text { Consuming } \\
\text { minimum number } \\
\text { of servings } \\
\text { recommended } \\
\text { ( } 3 \text { a day }) \\
\end{array}$ & $\begin{array}{c}\text { Consuming no. } \\
\text { of servings } \\
\text { recommended } \\
\text { based on caloric } \\
\text { intake }\end{array}$ \\
\hline \multirow{2}{*}{\multicolumn{4}{|c|}{ 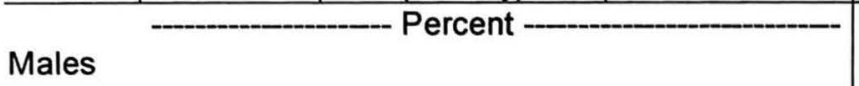 }} & \multirow{2}{*}{\multicolumn{4}{|c|}{$=0$}} \\
\hline & & & & & & & \\
\hline \multirow{2}{*}{$25-39$} & \multirow{2}{*}{1.9} & \multirow{2}{*}{90.6} & \multirow{2}{*}{75.5} & $20-29$ & 8 & 64 & 45 \\
\hline & & & & $30-39$ & 6 & 65 & 50 \\
\hline \multirow[t]{2}{*}{$40-58$} & \multirow[t]{2}{*}{1.9} & \multirow[t]{2}{*}{94.3} & \multirow[t]{2}{*}{88.7} & $40-49$ & 10 & 58 & 43 \\
\hline & & & & $50-59$ & 9 & 62 & 51 \\
\hline Total & 1.9 & 92.5 & 82.1 & Total $^{c}$ & 8 & 60 & 47 \\
\hline \multicolumn{4}{|l|}{ Females } & \multicolumn{4}{|l|}{ Females } \\
\hline \multirow{2}{*}{$25-39$} & \multirow{2}{*}{5.9} & \multirow{2}{*}{88.2} & \multirow{2}{*}{82.4} & $20-29$ & 13 & 39 & 35 \\
\hline & & & & $30-39$ & 10 & 42 & 37 \\
\hline \multirow[t]{2}{*}{$40-58$} & \multirow[t]{2}{*}{-} & \multirow[t]{2}{*}{100.0} & \multirow[t]{2}{*}{100.0} & $40-49$ & 10 & 46 & 42 \\
\hline & & & & $50-59$ & 11 & 46 & 44 \\
\hline Total & 4.8 & 90.5 & 85.7 & Total & 11 & 42 & 38 \\
\hline \multicolumn{8}{|c|}{$\begin{array}{l}\text { IFood Guide Pyramid: A Guide to Daily Food Choices. Washington, DC: US Dept of Agriculture, Human Nutrition } \\
\text { Information Service; } 2000 \text {. Home and Garden Bulletin No. } 252 \text {. } \\
\text { bUSDA/ARS (US Department of Agriculture, Agriculture Research Service). 2000b. Pyramid Servings Intakes by } \\
\text { Children and Adults: 1994-96, 1998. Online. ARS Community Nutrition Research Group Web site, available at: } \\
\text { http://www.barc.usda.gov/bhnrc/cnrg/ } \\
\text { cResults given for total includes ages } 20 \text { and over. }\end{array}$} \\
\hline
\end{tabular}




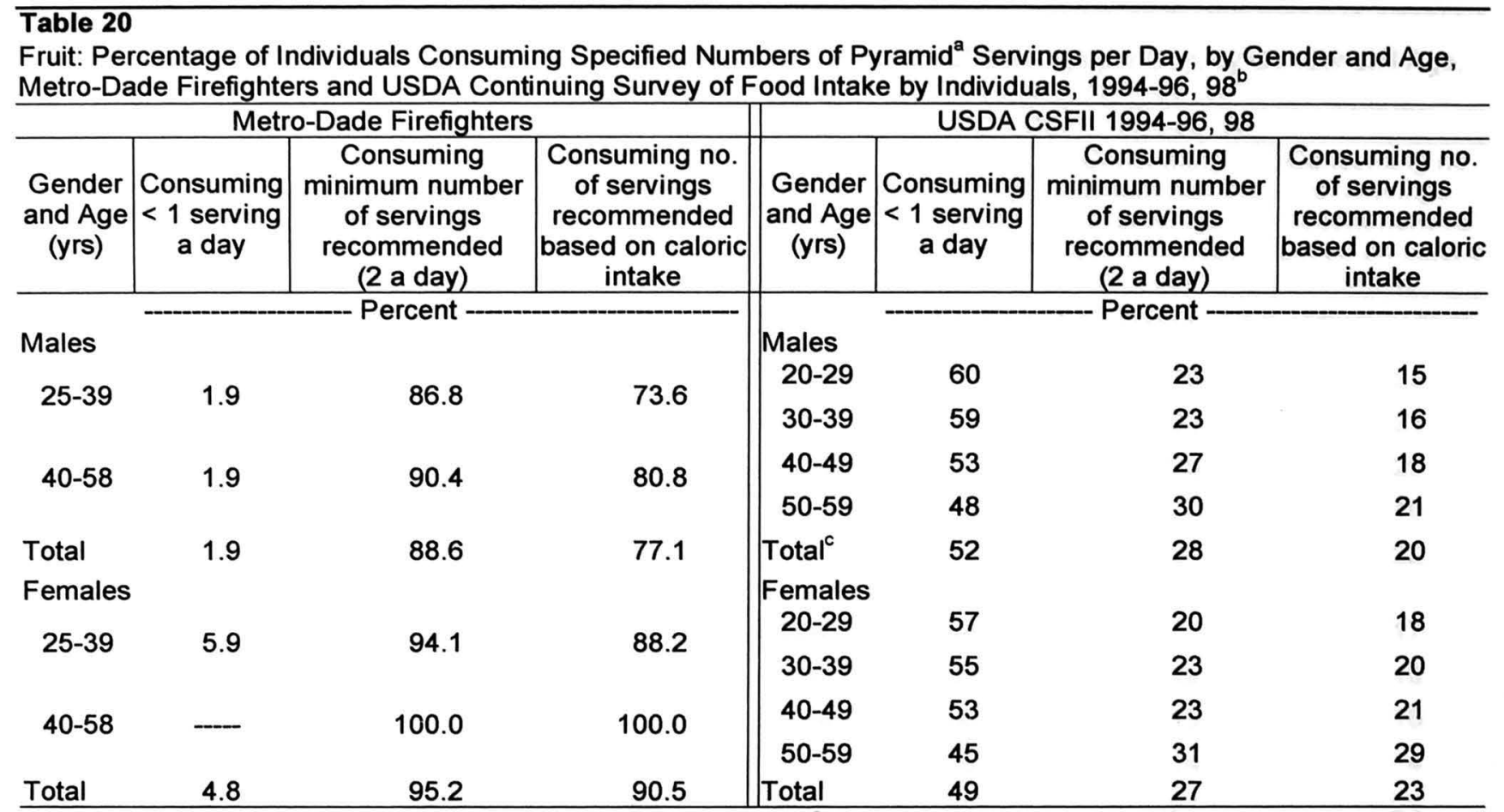

${ }^{a}$ Food Guide Pyramid: A Guide to Daily Food Choices. Washington, DC: US Dept of Agriculture, Human Nutrition Information Service; 2000. Home and Garden Bulletin No. 252.

'USDA/ARS (US Department of Agriculture, Agriculture Research Service). 2000b. Pyramid Servings Intakes by Children and Adults: 1994-96, 1998. Online. ARS Community Nutrition Research Group Web site, available at: http://www.barc.usda.gov/bhnrc/cnrg/

${ }^{\mathrm{c}}$ Results given for total includes ages 20 and over. 


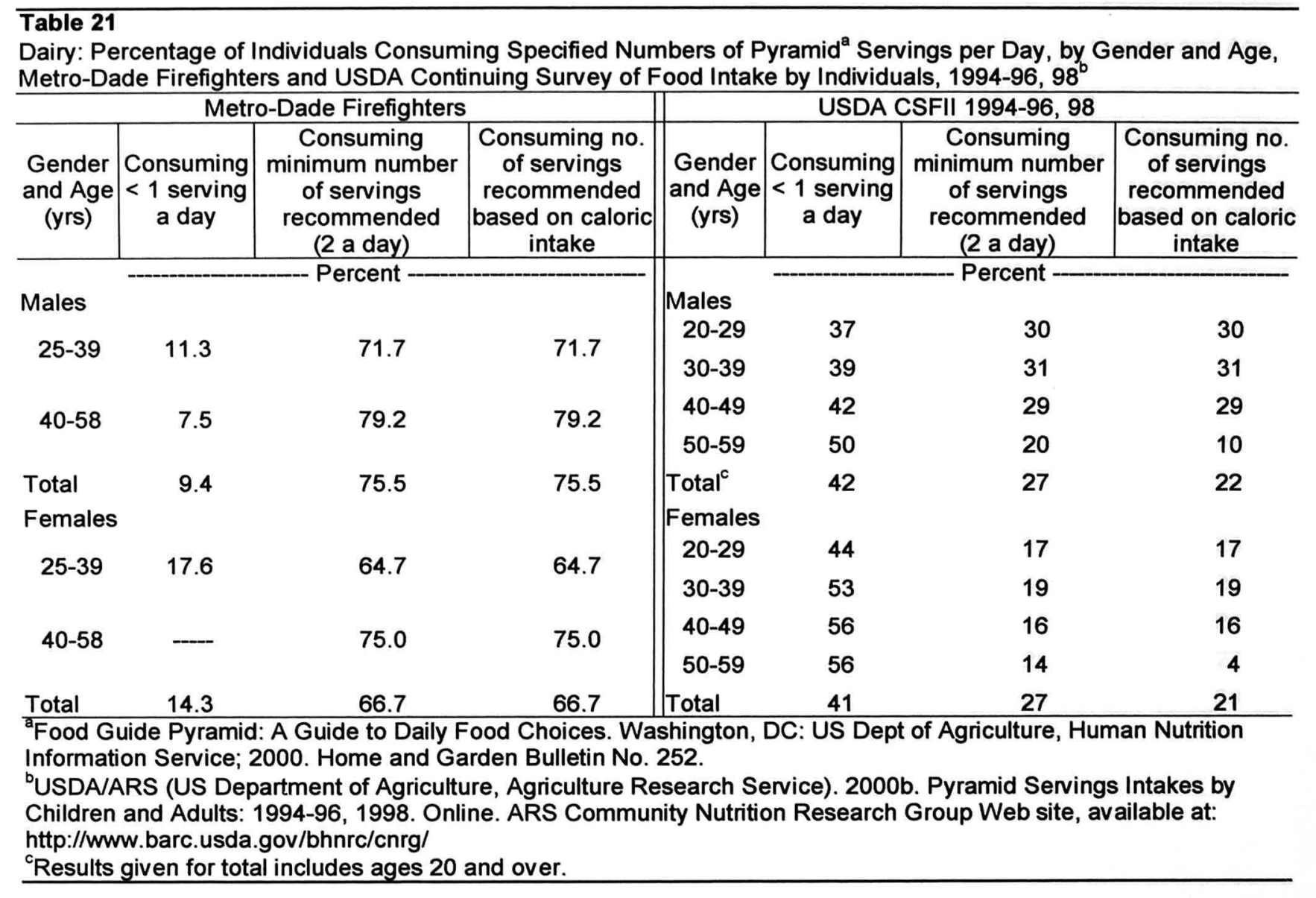




\section{Table 22}

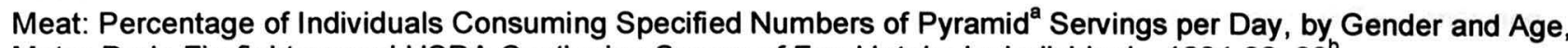
Metro-Dade Firefighters and USDA Continuing Survey of Food Intake by Individuals, 1994-96, $98^{\mathrm{b}}$

\begin{tabular}{|c|c|c|c|c|c|c|c|}
\hline \multicolumn{4}{|c|}{ Metro-Dade Firefighters } & \multicolumn{4}{|c|}{ USDA CSFII 1994-96, 98} \\
\hline $\begin{array}{l}\text { Gender } \\
\text { and Age } \\
\text { (yrs) }\end{array}$ & $\begin{array}{c}\text { Consuming } \\
<1 \text { serving } \\
\text { a day }\end{array}$ & $\begin{array}{c}\text { Consuming } \\
\text { minimum number } \\
\text { of servings } \\
\text { recommended } \\
\text { ( } 2 \text { a day) }\end{array}$ & $\begin{array}{c}\text { Consuming no. } \\
\text { of servings } \\
\text { recommended } \\
\text { based on caloric } \\
\text { intake }\end{array}$ & $\begin{array}{c}\text { Gender } \\
\text { and Age } \\
\text { (yrs) }\end{array}$ & $\begin{array}{c}\text { Consuming } \\
<1 \text { serving } \\
\text { a day }\end{array}$ & $\begin{array}{c}\text { Consuming } \\
\text { minimum number } \\
\text { of servings } \\
\text { recommended } \\
\text { ( } 2 \text { a day) }\end{array}$ & $\begin{array}{c}\text { Consuming no. } \\
\text { of servings } \\
\text { recommended } \\
\text { based on caloric } \\
\text { intake }\end{array}$ \\
\hline \multirow{2}{*}{\multicolumn{4}{|c|}{-_-- Percent -..... }} & \multirow{2}{*}{\multicolumn{4}{|c|}{ Percent - }} \\
\hline & & & & & & & \\
\hline \multirow{2}{*}{ 25-39 } & \multirow{2}{*}{--- } & \multirow{2}{*}{100.0} & \multirow{2}{*}{100.0} & $20-29$ & 2 & 65 & 54 \\
\hline & & & & $30-39$ & 1 & 69 & 60 \\
\hline \multirow{2}{*}{$40-58$} & \multirow{2}{*}{1.9} & \multirow{2}{*}{98.1} & \multirow{2}{*}{98.1} & $40-49$ & 1 & 68 & 59 \\
\hline & & & & $50-59$ & 1 & 64 & 57 \\
\hline \multirow{2}{*}{$\begin{array}{l}\text { Total } \\
\text { Females }\end{array}$} & \multirow[t]{2}{*}{0.9} & \multirow[t]{2}{*}{99.1} & \multirow[t]{2}{*}{99.1} & Total $^{\mathrm{C}}$ & 1 & 63 & 55 \\
\hline & & & & Females & & & \\
\hline \multirow{2}{*}{$25-39$} & \multirow{2}{*}{5.9} & \multirow{2}{*}{88.2} & \multirow{2}{*}{88.2} & $20-29$ & 7 & 29 & 25 \\
\hline & & & & $30-39$ & 4 & 30 & 28 \\
\hline \multirow{2}{*}{$40-58$} & \multirow{2}{*}{-} & \multirow{2}{*}{100.0} & \multirow{2}{*}{100.0} & $40-49$ & 5 & 30 & 28 \\
\hline & & & & $50-59$ & 4 & 29 & 27 \\
\hline Total & 4.8 & 90.5 & 90.5 & Total & 5 & 28 & 36 \\
\hline
\end{tabular}

${ }^{a}$ Food Guide Pyramid: A Guide to Daily Food Choices. Washington, DC: US Dept of Agriculture, Human Nutrition Information Service; 2000. Home and Garden Bulletin No. 252.

bUSDA/ARS (US Department of Agriculture, Agriculture Research Service). 2000b. Pyramid Servings Intakes by Children and Adults: 1994-96, 1998. Online. ARS Community Nutrition Research Group Web site, available at:

http://www.barc.usda.gov/bhnrc/cnrg/

Results given for total includes ages 20 and over. 


\section{Table 23}

Pyramid Tip - Fat: Mean Daily Intakes of Fat, by Gender and Age, Metro-Dade Firefighters and USDA Continuing Survey of Food Intake by Individuals, 1994-96, $98^{\circ}$

\begin{tabular}{|c|c|c|c|c|c|}
\hline \multicolumn{3}{|c|}{ Metro-Dade Firefighters } & \multicolumn{3}{|c|}{ USDA CSFII 1994-96, 98} \\
\hline $\begin{array}{l}\text { Gender and } \\
\text { Age (yrs) }\end{array}$ & $\begin{array}{l}\text { Food Energy } \\
\text { (Kilocalories) }\end{array}$ & \begin{tabular}{|c|} 
Fat (Percent of total \\
kilocalories)
\end{tabular} & $\begin{array}{l}\text { Gender and } \\
\text { Age (yrs) }\end{array}$ & $\begin{array}{l}\text { Food Energy } \\
\text { (Kilocalories) }\end{array}$ & $\begin{array}{c}\text { Fat (Percent of total } \\
\text { kilocalories) }\end{array}$ \\
\hline \multicolumn{3}{|l|}{ Males } & \multicolumn{3}{|l|}{ Males } \\
\hline \multirow{2}{*}{$25-39$} & \multirow{2}{*}{2124} & \multirow{2}{*}{31.7} & $20-29$ & 2667 & 33.0 \\
\hline & & & $30-39$ & 2669 & 34.2 \\
\hline \multirow{2}{*}{$40-58$} & \multirow{2}{*}{1934} & \multirow{2}{*}{33.0} & $40-49$ & 2403 & 34.1 \\
\hline & & & $50-59$ & 2217 & 34.3 \\
\hline Total & \multirow[t]{2}{*}{2029} & \multirow[t]{2}{*}{32.3} & Total & $2406^{c}$ & $33.7^{c}$ \\
\hline Females & & & Females & & \\
\hline \multirow{2}{*}{$25-39$} & \multirow{2}{*}{1629} & \multirow{2}{*}{27.2} & $20-29$ & 1758 & 31.8 \\
\hline & & & $30-39$ & 1687 & 32.4 \\
\hline \multirow{2}{*}{$40-58$} & \multirow{2}{*}{1215} & \multirow{2}{*}{26.4} & $40-49$ & 1639 & 33.8 \\
\hline & & & $50-59$ & 1576 & 32.7 \\
\hline Total & 1550 & 27.1 & Total & $1987^{c}$ & $32.9^{c}$ \\
\hline
\end{tabular}

${ }^{a}$ Food Guide Pyramid: A Guide to Daily Food Choices. Washington, DC: US Dept of Agriculture, Human Nutrition Information Service; 2000. Home and Garden Bulletin No. 252.

'USDA/ARS (US Department of Agriculture, Agriculture Research Service). 2000b. Pyramid Servings Intakes by Children and Adults: 1994-96, 1998. Online. ARS Community Nutrition Research Group Web site, available at: http://www.barc.usda.gov/bhnrc/cnrg/

${ }^{\mathrm{c}}$ Results given for total includes ages 20 and over. 
Metro-Dade Firefighters had better vegetable and fruit consumption compared to the CSFII, 1994-1996, 19898 (Tables 19-20). Approximately $92.5 \%$ and $82.1 \%$ of male and $90.5 \%$ and $85.7 \%$ of female Metro-Dade Firefighters consumed the minimum number of vegetables servings per day and the number of recommended servings based on caloric intake compared to the CSFII, $60 \%, 47 \%$, and $42 \%, 38 \%$ respectively (Table 19). This favorable difference was also apparent for the number of fruit servings (Table 20). For fruits and vegetables, $100 \%$ of the female Metro-Dade Firefighters, $40-58$ years, consumed the minimum and recommended number of servings based on caloric intake (Table 19-20).

Male Metro-Dade Firefighters had better dairy consumption than their female counterparts. Approximately $75.5 \%$ of male and $66.7 \%$ of female Metro-Dade Firefighters consumed the minimum number of dairy servings per day and the number of recommended servings based on caloric intake. However, both compared well to the CSFII, $27 \%, 22 \%$ of males and $27 \%, 21 \%$ of females respectively (Table 21 ).

Almost $100 \%$ of the male and $91 \%$ of female Metro-Dade Firefighters consumed the minimum and recommended number of servings from the meat group (Table 22). Their numbers were much greater than those of the CSFII, where $63 \%$ of males and $28 \%$ of females consumed the minimum number of servings and $55 \%$ of males and $36 \%$ of females consumed the recommended number of servings from the meat group.

The pyramid tip which includes fat intake was also compared between MetroDade Firefighters and the CSFII (Table 23). Female Metro-Dade Firefighters consumed less fat (27.1\%) than the CSFII (32.9\%); however, they were similar among males $32.3 \%$ versus $33.7 \%$. An even larger difference was seen between the caloric intakes of Metro- 
Dade Firefighters and the CSFII. Male Metro-Dade Firefighters consumed an average of 377 calories less than CSFII males, whereas female Metro-Dade Firefighters consumed an average of 437 calories less than CSFII females. Female Metro-Dade Firefighters, 4058 years, consumed the lowest number of calories, 1215 calories, among Metro-Dade Firefighters and CSFII adults.

\section{CVD Risk Factors}

The percent of Metro-Dade Firefighters reporting risk factors for CHD is presented in Table 24. Increased number of factors indicated an increased risk. Of the major non-modifiable risk factors, almost half of the Metro-Dade Firefighters had one or two risk factors. This is most likely due to that $83 \%$ of Metro-Dade Firefighters were male and $51.2 \%$ reported having a familial history of heart disease as risk factors. Approximately $8 \%$ of Metro-Dade Firefighters reported the largest number of major nonmodifiable risk factors. Only $3.1 \%$ reported having none.

About $60 \%$ of Metro-Dade Firefighters reported having one major modifiable risk factor probably owing to that $78 \%$ of Metro-Dade Firefighters were found to have a high BMI. Almost 20\% reported having no major modifiable risk factors. Metro-Dade Firefighters had the most number of risk factors from the additional contributing risk factors category. Approximately $21 \%$ reported one risk factor while $45 \%$ reported three to four risk factors. This may be due to approximately $61 \%$ of Metro-Dade Firefighters that had low total folate intake, $54 \%$ had high total fat intake, $51 \%$ had high saturated fat intake and $43 \%$ had high cholesterol intake. Overall, approximately $30 \%$ of Metro-Dade Firefighters had four total modifiable risk factors. More than half of the Metro-Dade Firefighters had reported five or more total risk factors while $4 \%$ had $8-9$. Only $1.6 \%$ had 


\section{Table 24}

Percent of Metro-Dade Firefighters Reporting Risk Factors for Coronary Heart Disease (CHD) ( $n=127)$

\begin{tabular}{|c|c|c|c|c|c|c|c|c|c|c|}
\hline \multirow{2}{*}{$\begin{array}{c}\text { No. of } \\
\text { Risk } \\
\text { Factors }\end{array}$} & \multicolumn{2}{|c|}{$\begin{array}{c}\text { Major Non-Modifiable } \\
\text { Risk Factors }^{\mathrm{a}}\end{array}$} & \multicolumn{2}{|c|}{$\begin{array}{l}\text { Major Modifiable } \\
\text { Risk Factors }^{b}\end{array}$} & \multicolumn{2}{|c|}{$\begin{array}{l}\text { Additional Contributing } \\
\text { Modifiable Risk Factors } \\
\end{array}$} & \multicolumn{2}{|c|}{$\begin{array}{l}\text { Total Modifiable } \\
\text { Risk Factors } \\
\end{array}$} & \multicolumn{2}{|c|}{$\begin{array}{l}\text { Total Risk } \\
\text { Factors }\end{array}$} \\
\hline & $\mathbf{n}$ & $\%$ & $\mathbf{n}$ & $\%$ & $\mathbf{n}$ & $\%$ & $\mathbf{n}$ & $\%$ & $\mathbf{n}$ & $\%$ \\
\hline 0 & 4 & 3.1 & 25 & 19.8 & 27 & 21.3 & 11 & 8.7 & 2 & 1.6 \\
\hline 1 & 59 & 47 & 76 & 59.8 & 26 & 20.5 & 22 & 17.3 & 7 & 5.5 \\
\hline 2 & 54 & 43 & 21 & 16.5 & 17 & 13.4 & 18 & 14.2 & 13 & 10 \\
\hline 3 & 10 & 7.9 & 5 & 3.9 & 45 & 35.4 & 15 & 11.8 & 21 & 17 \\
\hline 4 & & & & & 12 & 9.4 & 38 & 29.9 & 16 & 13 \\
\hline 5 & & & & & & & 18 & 14.2 & 25 & 20 \\
\hline 6 & & & & & & & 4 & 3.1 & 20 & 16 \\
\hline 7 & & & & & & & 1 & 0.8 & 18 & 14 \\
\hline 8 & & & & & & & & & 4 & 3.1 \\
\hline 9 & & & & & & & & & 1 & 0.8 \\
\hline
\end{tabular}

${ }^{a}$ Major non-modifiable risk factors (0-5) include: age, gender, ethnicity, familial and self history of heart disease (AHA)

${ }^{\mathrm{b}}$ Major Modifiable risk factors (0-5) include: smoking, high blood pressure, physical inactivity, obesity/overweight, diabetes (AHA).

'Additional contributing modifiable risk factors (0-4) include: total fat intake, saturated fat intake, dietary cholesterol, folate intake. 
reported no risk factors. On average, Metro-Dade Firefighters had reported more modifiable risks $(2.96 \pm 1.7)$ than non-modifiable risks $(1.55 \pm 0.7)$. The mean number of total risk factors reported by Metro-Dade Firefighters was $4.5 \pm 2.0$.

The mean numbers of risk factors for $\mathrm{CHD}$ were also compared by age groups (Table 25). Older Metro-Dade Firefighters, 40-58 years, had reported significantly $(p<.05)$ more risks than younger Metro-Dade Firefighters, 25-39 years, in all of the categories, except additional contributing risk factors. A significant $(\mathrm{p}<.05)$ difference between the age groups, $25-39$ years and $40-58$ years, was noted in the total modifiable risk category, $2.7 \pm 1.6$ and $3.3 \pm 1.8$ respectively. Risk factors by gender and age groups were compared but not presented in a table. Older male Metro-Dade Firefighters had reported significantly more risks on average in the major non-modifiable $(p<0.01)$, major modifiable $(\mathrm{p}<.001)$ and total risk factors $(\mathrm{p}<0.05)$ categories compared to younger male Metro-Dade Firefighters. 


\section{Table 26}

The Mean Number of Risk Factors for Coronary Heart Disease (CHD), by age, Metro-Dade Firefighters $(n=127)$

\begin{tabular}{|c|c|c|c|c|}
\hline Risk Factors & Age (yrs) & $\mathbf{n}$ & Mean $\pm S^{a}$ & $\mathbf{P}$ \\
\hline \multirow[t]{2}{*}{ Major Non-Modifiable ${ }^{b}$} & 25-39 & 70 & $1.4 \pm 0.6$ & \multirow{2}{*}{0.008} \\
\hline & $40-58$ & 57 & $1.7 \pm 0.7$ & \\
\hline \multirow[t]{2}{*}{ Major Modifiable $^{c}$} & $25-39$ & 70 & $0.8 \pm 0.6$ & \multirow{2}{*}{0.05} \\
\hline & $40-58$ & 57 & $1.3 \pm 0.8$ & \\
\hline \multirow[t]{2}{*}{ Additional Contributing Modifiable ${ }^{d}$} & $25-39$ & 70 & $1.9 \pm 1.3$ & \multirow{2}{*}{ NS } \\
\hline & $40-58$ & 57 & $2.0 \pm 1.4$ & \\
\hline \multirow[t]{2}{*}{ Total Modifiable } & $25-39$ & 70 & $2.7 \pm 1.6$ & \multirow{2}{*}{0.05} \\
\hline & $40-58$ & 57 & $3.3 \pm 1.8$ & \\
\hline \multirow[t]{2}{*}{ Total } & $25-39$ & 70 & $4.1 \pm 1.8$ & \multirow{2}{*}{0.05} \\
\hline & $40-58$ & 57 & $5.0 \pm 2.2$ & \\
\hline
\end{tabular}

${ }^{\mathrm{a}} \mathrm{SD}=$ Standard Deviation

${ }^{b}$ Major non-modifiable risk factors (0-5) include: age, gender, ethnicity, familial and self history of heart disease (AHA)

${ }^{\mathrm{C}}$ Major Modifiable risk factors (0-5) include: smoking, high blood pressure, physical inactivity, obesity and overweight, diabetes (AHA)

${ }^{d}$ Additional contributing modifiable risk factors $(0-4)$ include: total fat intake, saturated fat intake, dietary cholesterol, folate intake. 


\section{Dietary Analysis}

\section{DISCUSSION}

Total caloric intakes of Metro-Dade Firefighters by age and gender compared favorably to CSFII and to NHANES III, 1988-1994. The mean total calories for US adults from NHANES III was $2095 \mathrm{kcal}$ compared to $1950 \mathrm{kcal}$ for Metro-Dade Firefighters. US males and females consumed an average of $2478 \mathrm{kcal}$ and $1751 \mathrm{kcal}$ respectively compared to Metro-Dade Firefighters, $2029 \mathrm{kcal}$ and $1550 \mathrm{kcal}$ respectively. Differences were even more apparent when comparisons were made by age groups. US males, 20-39 yrs and 40-59 years consumed approximately $2949 \mathrm{kcal}$ and $2443 \mathrm{kcal}$ respectively, compared to $2124 \mathrm{kcal}$ and $1934 \mathrm{kcal}$ by Metro-Dade Firefighters. Similar differences were seen in females by age groups as well. Although the caloric intake of Metro-Dade Firefighters fell within the recommended range by the USDA Food Guide Pyramid, 1600-2200 kcal, it was thought that their caloric intakes would be higher considering their high BMIs and reported high levels of physical activity. This suggests that either caloric intakes were underreported or physical activity was over reported. A study done by Subar et al (2001) found that when compared to 24 hour food recalls, the Block FFQ, the Dietary Health Questionnaire (DHQ) and the Willet FFQ underestimated absolute nutrient intakes for men. Correlation and attenuation coefficients were slightly higher for the DHQ than for the Block FFQ, and both were better than the Willet FFQ in models unadjusted for energy (kcal). Energy increased correlation and attenuation coefficients dramatically for the Willet FQ and modestly for the other two FFQs, suggesting that energy adjustment, in general, reduces measurement error. It was 
suggested that the lack of portion size explanation in the Willet FFQ attributed to the differences in intakes.

Total carbohydrate intake (46\%) was about $10 \%$ below the USDA Food Guide Pyramid recommendations (55-60\% of total energy). The mean number of servings from the Food Guide Pyramid were above the recommended ranges for all of the food groups except the grain group, which is a main source of carbohydrates in the diet. This explains the lower carbohydrate intake by Metro-Dade Firefighters compared to the Food Guide Pyramid.

Almost $100 \%$ of Metro-Dade Firefighters consumed five servings of fruits and vegetables as recommended by the National Cancer Institute (NCI) "5 a Day" campaign and the "5 a Day for Better Health" program (Healthy People, 1998), compared to $22.7 \%$ of US adults (CDC, 1996). However, fiber intake for all Metro-Dade Firefighters $(17 \pm 8.5 \mathrm{gm})$ was notably lower than the recommended amount of $25-30 \mathrm{gm}$ per day by the AHA. Comparing to NHANES III, 1988-1994, Metro-Dade Firefighters' fiber intake was slightly better than US adults, 15.6 gm per day. The low fiber intake of Metro-Dade Firefighters is surprising considering their high intakes of fruits and vegetables. This suggests that Metro-Dade Firefighters are consuming too many low-fibrous fruits and vegetables. For instance, their average serving per day for iceberg lettuce was $2.78 \pm 1.4$ and for juices was $1.07 \pm 0.43$. Metro-Dade Firefighters should try to increase their fiber intake by consuming more whole grains and fibrous vegetables and fruits such as bran cereals, spinach, and fresh fruits.

The major source of protein was of animal sources. Metro-Dade Firefighters consumed twice the recommended amount of servings for dairy and three to four times 
for the meat group. Although there was a significant difference between two age groups for protein intake, both groups consumed well above the USDA recommendations (10$15 \%$ ). The younger age ( $25-39$ years) group's protein intake was $20 \%$ of total calories, compared to $17 \%$ for the older age group. This is consistent with the finding that younger Metro-Dade Firefighters consumed significantly more servings from the meat group than the older group. Comparisons to CSFII showed that a greater percentage of Metro-Dade Firefighters than US aduits consumed the minimum number of servings and the recommended number of servings from the meat group based on caloric intake.

The diet composition of the Metro-Dade Firefighters, particularly the younger firefighters in this study seems to be low in carbohydrate, high in protein, low in calcium, satisfactory in fruit and vegetables intake yet low in fiber suggesting that some MetroDade Firefighters are participating in today's popular modified-high protein diet. These diets include $40 \%-45 \%$ of total calories from carbohydrates, with fat and protein each providing $25 \%-30 \%$ of total calories (Luscombe et al, 2002). Further analysis found that $21.3 \%$ of Metro-Dade Firefighters had diets that consisted of less than $45 \%$ of calories from carbohydrates and more than $20 \%$ from protein. Intakes of protein supplements such as protein bars and shakes were not reported in the FFQ but were ubiquitous in the firehouses visited. Also, per comments made by the Metro-Dade Firefighters, it was obvious to the researcher that many were following high protein or fad diets. This is consistent with the findings of Winton (2002) which found almost 17\% of Metro-Dade Firefighters were following a high-protein low-carbohydrate diet.

Although their diet composition is in accordance to the new DRIs (Institute of Medicine, 2002) for macronutrients ( $45 \%-65 \%$ carbohydrate, $10-35 \%$ protein, $20-35 \%$ 
fat), caution with high-protein diets is recommended for those individuals that may be predisposed to kidney disease (Einstein, et al, 2002; Reddy et al, 2002). A review of experimental and epidemiologic data on high-protein diets by Einstein et al, 2002 indicated that the consumption of protein two to three times the DRI contributes to urinary calcium loss, and may increase the risk of bone loss. Considering mean calcium intakes, dietary or with supplements, were about $57 \%-67 \%$ below the DRI, Metro-Dade Firefighters may be even more predisposed to bone loss.

$B M I$

Firefighters are perceived by the media and the general public to be in good physical condition or portray a lean physique due to the nature of the their job. Therefore, it was expected that the majority would have BMIs that fall into the acceptable or healthy weight category. However, that was only the case for only $22 \%$ of the Metro-Dade Firefighters. The BMI's of Metro-Dade firefighters were high, $78 \%$ had BMI's $\geq 25$. This may suggest that overweight and obesity may be the most common CVD risk factors among this group. The prevalence of overweight and obesity in Metro-Dade Firefighters is not surprising when new data released from NHANES $1999-2000$ found $64 \%$ of US adults to be overweight or obese.

The majority of Metro-Dade Firefighters found to be overweight was consistent with two other studies. One study by Kay et al, (2001) found $84 \%$ of firefighters to be overweight. Fourteen percent of them were found to be obese compared to $30 \%$ of Metro-Dade Firefighters. However, the number of obese cases in Kay et al, (2001) may have been underreported since, in their study, height and weight were self-reported. Kay et al, (2001) who assessed firefighters' CVD related knowledge and behaviors found that 
$44 \%$ considered themselves overweight while $53 \%$ considered themselves to be "about right."

,Kales et al, (1999) reported the mean BMI of firefighters in their study to be

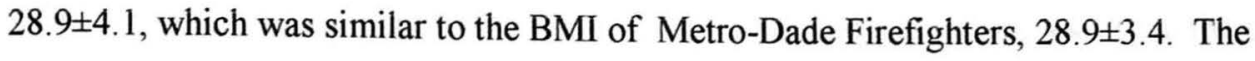
prevalence of overweight in Metro-Dade Firefighters was also consistent with the study of Kales et al, (1999) which found $87 \%$ of the firefighters to be overweight. The prevalence of obesity, $34 \%$, was similar to that of Metro-Dade Firefighters, $30 \%$.

Unlike past NHANES, the most recent NHANES examined racial/ethnic differences among Hispanics. However, data including healthy weight by ethnicity has not yet been released. Considering the small sample size of ethnic groups in our study, BMI's were not investigated by ethnicity. However, it was feasible to examine white Metro-Dade Firefighters in comparison to non-whites subjects. We found that significantly $(\mathrm{p}<0.001)$ more white Metro-Dade Firefighters were overweight and significantly $(p<0.001)$ more non-white Metro-Dade Firefighters were obese. This finding was similar to NHANES 1999-2000 which also found more whites to be overweight and less to be obese compared to blacks and Hispanics. More white male Metro-Dade Firefighters (80.3\%) were overweight and obese compared to white US males from NHANES $1999-2000(67.5 \%)$. The small number of women $(n=21)$ also made comparisons between the genders impractical. Overweight and obesity seems to be more prevalent among Metro-Dade Firefighters and other firefighters (Kayes et al, 2001, Kales et al, 1999) when compared to the US population and hence, may suggest firefighters are at greater risk for CVD. 
The prevalence of overweight and obesity in the US can be partly attributed to their sedentary lifestyle. The CDC in 1992 found that $58 \%$ of US adults reported irregular or no leisure time physical activity. In 2001 , only $22 \%$ of Americans met the CDC definition for regular physical activity. The marked increase in obesity in the past decade is contrary to the insinuations that "leisure" exercise is providing ample calorieburning exercise. However, firefighters have knowledge of accepted physical activity guidelines to maintain cardiovascular fitness (Kay et al, 2001). Although, knowledge usually does not correlate with behavior, Metro-Dade Firefighters reported being more active than the general US population. Eighty-eight percent of Metro-Dade Firefighters reported engaging in moderate to vigorous exercise, which is consistent with findings of Kay et al, (2001) that found $84 \%$ of firefighters exercised regularly. Had we measured body fat percentage, we would have been able to determine if high lean body mass explained the high percentage of BMIs $\geq 25$ and reported increased physical activity among firefighters. We found only one study, Weiss et al (1984), that measured body fat percentage in Metro-Dade Firefighters. Excess fatness (body fat percentage $>21 \%$ ) was found in $52 \%$ of their sample ( $\mathrm{n}=603$ ) of firefighters. Hypertension is approximately three times more common in obese than normal-weight persons (Van Itallie, 1985) and considered a major modifiable CVD risk factor (AHA, 2001). Although hypertension was reported by only $5.5 \%$ of Metro-Dade Firefighters, they all had BMIs $>30$. Hence, the prevalence of overweight and obesity should be addressed as a major CVD risk factor in firefighters. 


\section{Fat Intake}

Metro-Dade Firefighters had lower total fat and saturated fat intakes than US adults from NHANES III, 1988-1994 and CSFII, 1994-1996, 1998. Total fat and saturated fat intake was lower for Metro-Dade Firefighters, $69 \pm 40 \mathrm{gm}$ and $23 \pm 13 \mathrm{gm}$ respectively, compared to US adults from NHANES III, $81 \mathrm{gm}$ and $28 \mathrm{gm}$, respectively. Percent of calories from fat was also lower for Metro-Dade Firefighters, $32 . \%$ for total fat and $10.4 \%$ for saturated fat compared to NHANES III, $34 \%$ and $12 \%$ respectively. Comparisons of fat intakes by age and gender by Metro-Dade Firefighters to CSFII, 1994-1996, 1998 were also similar to NHANES III, 1988-1994. The differences between total fat intakes was slightly higher in female Metro-Dade Firefighters as compared to US females. Percent of calories from total fat intake for female Metro-Dade Firefighters, 2539 years and $40-58$ years, was $27.2 \%$ and $26.4 \%$ compared to $34 \%$ and $34.4 \%$, US adults fro NHAMES III. Dietary cholesterol intake was greater for all Metro-Dade Firefighters, $316 \pm 183 \mathrm{mg}$, compared to US adults, $270 \mathrm{mg}$. Although the Metro-Dade Firefighters' fat intakes fared better than US adults, they consumed above the AHA recommendations. Previous studies, (Blankenship and Hagan, 1986 Weiss et al, 1984) had found the diets of firefighters to be high in total fat, saturated fat, cholesterol, and sodium. Considering Metro-Dade Firefighters' had high intakes from the meat and dairy group, which are the major sources of fat, saturated fat, and cholesterol in the diet, their higher fat intakes above the AHA recommendation was not surprising.

Kay et al, (2002) reported that $28 \%$ of the firefighters were told by their health care providers that they have high blood cholesterol. The median percentage of US adults who have been told that they have high blood cholesterol is $29.7 \%$ for whites, $26 \%$ 
for African-Americans, and $25.6 \%$ for Hispanics (CDC, 1997). A $10 \%$ decrease in cholesterol levels may result in an estimated 30\% reduction the incidence of CHD (CDC, 2000). 'Although blood cholesterol levels were not measured in this study, the Seven Countries Study showed a strong positive association between saturated fatty acids and dietary cholesterol in relation to serum cholesterol and 25-year mortality rates from coronary heart disease (Kromhaut et al, 1995). Some research shows that serum cholesterol is more affected by dietary fat than dietary cholesterol intake (Morgan et al, 1997). The AHA considers high blood cholesterol, which is affected by diet and heredity, as a major risk factor for CVD (AHA, 1999). Hence, fat intake is an important modifiable risk factor among firefighters and should be addressed by nutrition professionals.

Folate Intake

The mean total folate intake for Metro-Dade Firefighters, without supplements, was slightly below $(385 \pm 173 \mathrm{mcg}$ ) the 1999 DRI for folate of $400 \mathrm{mcg}$. However, once supplements were included, they were about $148 \mathrm{mcg}$ above the 1999 DRI. Folate intake with or without supplements was greater than the average intake of the US population, 283.4 mcg per day based on NHANES III, 1988-1994. Comparisons to CSFII were also favorable. The percentage of Metro-Dade Firefighters consuming $400 \mathrm{mcg}$ total folate was greater than CSFII adults, $38.6 \%$ verses $25.8 \%$. Considering fortification of cereal grain products with folic acid did not begin until 1998, comparisons to NHANES III and CSFII 1996-1998 are not practical. If folate intake by Metro-Dade Firefighters was corrected for fortification and supplement use, it would be expected that mean total folate intakes would be higher. However, due to the Metro-Dade Firefighters' much greater 
consumption of servings of fruits and vegetables than US adults, CSFII, 1994-1996, 9 servings verses 4.9 servings, it is plausible that Metro-Dade Firefighters' total folate intakes may still be greater than US adults. Findings regarding folate intake among ethnic groups were consistent with CSFII and NHANES III in that more AfricanAmericans failed to meet the DRI for folate than whites and Hispanics.

Folate intake recommendations vary under different conditions. Plasma and dietary folate has been found to be inversely related with plasma homocysteine levels, which has been found to be an independent risk factor for CVD (Boushey et al, 1995; Dalery et al, 1995; Tucker et al, 1996; Selhub et al, 1993; Selhub et al, 1995; Verhoef et al, 1998). Intake of approximately $350 \mathrm{mcg}$ of folate is required to maintain normal plasma homocysteine levels, $650 \mathrm{mcg}$ for those with elevated plasma homocysteine, and about $400 \mathrm{mcg}$ for women planning to become pregnant (Krishnaswamy and Madhavan, 2001). Since plasma homocysteine levels in Metro-Dade Firefighters was not measured in this study, it is not certain exactly how much folate is needed to affect homocysteine levels to reduce the risk of CVD. However, Bazzano et al, (2002) found an inverse relationship between dietary intake of folate and subsequent risk of stroke and CVD. After adjusting for CVD risk factors and dietary factors, participants who consumed at least $300 \mathrm{mcg}$ of folate per day had a $20 \%$ lower risk of stroke and $13 \%$ lower risk for CVD than those consuming less than $136 \mathrm{mcg}$ per day. Interestingly, when dietary and supplemented folate intakes were compared among ethnic groups, significance $(\mathrm{p}<.05)$ was only found at $75 \%$ of the DRI ( $300 \mathrm{mcg}$ ), the amount required to lower risk as reported by Bazzano et al, (2002). A significantly greater percentage (44.4\%) of AfricanAmericans failed to consume $300 \mathrm{mcg}$ of folate daily. The same percentage failed to meet 
the DRI for folate of $400 \mathrm{mcg}$. In addition to racial heritage (African-American) as a major CVD risk factor (AHA, 1999), almost half of the African-American Metro-Dade Firefighters may be at risk due to their low folate intake.

Since increasing age is a major CVD risk factor (AHA, 1999), it would be prudent for Metro-Dade Firefighters in the older age group to have a higher folate intake. However, it was found that a smaller percentage of older Metro-Dade Firefighters, 40-58 $\mathrm{yr}$, had folate intakes of at least $300 \mathrm{mcg}$ ( $75 \%$ of the DRI) and $400 \mathrm{mcg}(100 \%$ of the DRI) than the younger group, 25-39 years, dietary or with supplements. Therefore, in addition to increasing age, $37 \%$ or $28 \%$ of the older Metro-Dade Firefighters, based on diet or with supplements, may also include low folate status as a CVD risk factor.

Males had higher mean dietary folate intakes than females. Male gender is another major CVD risk factor (AHA, 1999). Based on dietary folate intake, $27 \%$ of male Metro-Dade Firefighters and $48 \%$ of female Metro-Dade Firefighters would be at a higher risk for stroke or CVD since their intakes were below $300 \mathrm{mcg}(75 \%$ of the DRI). However, when supplements were included, more male Metro-Dade Firefighters had total folate intakes below $300 \mathrm{mcg}$. Hence, $22 \%$ of the male Metro-Dade Firefighters and $14 \%$ of the females would be at a higher risk for stroke and CVD. Looking at Metro-Dade Firefighters as a group, $31 \%$ would be at a higher risk based on diet alone compared to $21 \%$ if supplements were included.

It is recommended by many organizations, including the March of Dimes, that women planning to become pregnant meet the DRI of $400 \mathrm{mcg}$ of folate to prevent neural tube defects (Green, 2002). The DRI was met by a greater percentage of female MetroDade Firefighters when supplements were included (71\%) than diet alone (29\%). This is 
also the same percentage of female Metro-Dade Firefighters who took multivitamins than those who did not. Evidently, supplement use appears to be an important determinant in meeting the DRI and pre-pregnancy needs of folate for women in this study since 20 of the 21 were in their child-bearing years.

\section{Folate Sources}

The bioavailability of supplements of folic acid under fasting conditions are close to $100 \%$ (Gregory, 1997), whereas the absorption of folate from foods varies from $25 \%$ to $70 \%$ with a mean close to about $50 \%$ (Babu, Srikantia, 1976). The maximum bioavailability of folate is found in egg yolk (72.2\%) followed by cow's liver (55.7\%), which ranked as the $6^{\text {th }}$ major source of folate in the diet of Metro-Dade Firefighters. The top nine folate sources for the Metro-Dade Firefighters was consistent with the findings of Subar et al (1989) who found that the same food sources, except for white rice, was in the top 10 major food contributors of folate in the US diet according to NHANES II, 1976-1980 data. Rice and beans, a staple food in the Latin diet, provided $41 \%$ of the total folate for the Metro-Dade Firefighters. Orange juice which ranked $3^{\text {rd }}$ as a source of folate in the diets of Metro-Dade Firefighters and $1^{\text {st }}$ in NHANES II has only $13 \%$ bioavailability. However, turkey and chicken liver which has high bioavailability ranked $2^{\text {nd }}$ as a folate source. As Subar et al (1989) pointed out, another food source such as beans may be lower in rank yet provide greater bioavailability. Not only should bioavailability be a factor in meeting folate requirements but fat as well. Although liver is a great source of folate for Metro-Dade Firefighters, it is also high in total fat, saturated fat, and cholesterol. They would benefit from learning the bioavailability of different 
low-fat sources of folate to help them meet the DRI for folate and also lower their high fat intakes, thereby lower their risk for CVD.

Nutrient Intake and Supplement Use

Vitamin A was the only micronutrient found to surpass the tolerable upper levels (UL) established by the Institute of Medicine, 2001. Hypervitaminosis A can lead to three major adverse effects: birth defects, liver abnormalities, and reduced bone mineral density that may result in osteoporosis (Institute of Medicine, DRI: Vitamin A, 2001). Toxicity usually results from an excess intake of vitamin A in supplements. The risk of adverse health effects increases at intakes greater than the UL. Dietary intake of vitamin A in Metro-Dade Firefighters approached the UL of 10,000 IU. When supplement intake was factored in, vitamin A intake was almost $3500 \mathrm{IU}$ above the UL. This is of concern since almost $10 \%$ of Metro-Dade Firefighters reported currently taking Vitamin A, especially for those whom intakes of calcium were below the DRI and are consuming high protein diets.

Although folate, vitamin B6, and vitamin B12 have been found to influence plasma levels of homocysteine (Chasen-Tuber, 1996; Dalery, 1995), folate has been found to be the most important determinant of the three and indirectly a risk factor for CVD (Boushey, et al, 1995; Verhoef et al, 1996, Pancharuniti et al, 1994). Besides their lower importance, vitamins B6 and B12 may not play a role in the risk for CVD in Metro-Dade Firefighters since their dietary intake of vitamins B6 and B12 were two to three times the DRI, six to eight times with supplements.

Muntwyler et al, (2002) found that in a large cohort of apparently healthy US male physicians, self-selected supplementation with vitamin $\mathrm{E}$, vitamin $\mathrm{C}$, or 
multivitamins was not associated with a significant decrease in total CVD or CHD mortality. This is consistent with the position by AHA which states that scientific evidence does not yet support recommending vitamin $\mathrm{E}$ or other antioxidant supplements to prevent CVD (AHA, 1999). However, Metro-Dade Firefighters are routinely exposed to a large number of toxic substances (i.e. carbon monoxide, benzene, and cyanide) (Melius, 2001) and thereby, may have an increased need for antioxidants.

Cyanide intake, which has been associated with cigarette smoking, (Stedman, 1968) is also a potential fire smoke contaminant with cardiac toxicity (Melius, 1995). Some studies have found that cigarette smokers need at least $200 \mathrm{mg}$ of vitamin C per day to obtain serum ascorbate concentrations equivalent to nonsmokers in meeting the DRI (Eiserich et al, 1995, Schectman et al, 1991). Another study showed that smokers require an average of $658 \mathrm{mcg}$ of folate per day to achieve a plasma folate level comparable to that of a nonsmoker consuming $200 \mathrm{mcg} /$ day (Piyathilake et al, 1994). If these studies were extrapolated to Metro-Dade Metro-Dade Firefighters, their dietary intakes of vitamin $\mathrm{C}$ and folate would be insufficient. Although, vitamin $\mathrm{C}$ intake with supplements was twice the recommended amount for smokers, this would only apply to the $38 \%$ of Metro-Dade Firefighters that take additional vitamin C. Studies are needed to determine the intakes needed of vitamin $\mathrm{C}$ and folate, dietary and supplements, by firefighters to obtain serum ascorbate concentrations and plasma folate levels comparable to nonsmokers.

\section{CVD Risk Factors}

Metro-Dade Firefighters had on average 4.5 CVD risk factors of which approximately three were modifiable risk factors. Other studies (Glueck et al, 1996; 
Weiss et al, 1984) have not only found CVD risk factors to be in high-risk range and increased frequency in firefighters but that $\mathrm{CHD}$ events were associated with modifiable CHD risk factors. Metro-Dade Firefighters most at risk were older males, probably attributed to their higher BMIs, fat intake and non-modifiable risk factors. However, three modifiable risk factors, which were diet-related, were found in increased frequency in all Metro-Dade Firefighters: high BMIs, high fat intakes and low dietary folate intake, particularly in African-Americans, should be addressed in Metro-Dade Firefighters to reduce the potential health hazards associated with CVD. The large percentage of overweight Metro-Dade Firefighters are especially at risk for CVD. Intervention is needed to help them maintain or achieve a healthy weight in a healthy manner. Education regarding better nutritional and health practices would particularly be beneficial.

\section{Limitations of the Study}

The sample size of this study was small $(\mathrm{n}=127)$ to make comparisons to epidemiological studies such as NHANES and CSFII. Also, white males made up almost half of the Metro-Dade Firefighters in our sample. Therefore, it was difficult to ascertain sufficient numbers of females, Hispanics and African-Americans to make comparisons by gender and ethnicity.

In 2000, the DRIs and the USDA changed from reporting folate intake as micrograms of total folate to micrograms of dietary folate equivalents (DFEs) to reflect the fortification of cereal grains that began in 1998. "DFEs adjust for nearly $50 \%$ lower bioavailability of food folate compared with that of folic acid: $1 \mathrm{mcg}$ of DFE $=0.6 \mathrm{mcg}$ of folic acid from fortified food or as a supplement taken with meals $=1 \mathrm{mcg}$ of food folate $=0.5 \mathrm{mcg}$ of a supplement taken on an empty stomach" (Institute of Medicine, p196, 
2000). At the time of this study, scoring folate as DFEs was not available from the Harvard School of Health, Nutrition Department. It is presumed micrograms of DFEs would report better folate intakes for Metro-Dade Firefighters.

Subjects' answers to questionnaires may have been biased for a variety of reasons. Although it was explained that all assessments would remain confidential, some expressed apprehension that results may affect employment. Also, fire houses are known for their family atmosphere. Social desirability caused by peer pressure and information bias may have affected their answers.

On the other hand, fire stations were selected at random and $86 \%$ of the firefighters from the random sample of fire stations participated in the study. Therefore, results are extrapolative to the rest of the fire stations in Metro-Dade County. Summary of Significant Findings

Since firefighters have been known to have high fat and unhealthy diets, it was expected that Metro-Dade Firefighters would have high fat intakes, low fruit and vegetable intakes and consequently low folate intakes. It was found that their diets were high in fat but that they also had very high intakes of fruits and vegetables. However, they were not able to meet the DRI for folate without supplement use or by consuming an additional serving of fruit or vegetable rich in folate. Significantly more AfricanAmericans failed to meet at least $75 \%$ of the DRI than whites or Hispanics. Folate intake by Metro-Dade Firefighters compared favorably to US adults. Liver was surprisingly a top food source of folate in the Metro-Dade Firefighters' diet.

Since increasing age is a risk factor for CVD, it was expected that older firefighter had better nutritional practices. Older Metro-Dade Firefighters had significantly higher 
intakes of vegetables than younger firefighters. Younger firefighters also had significantly higher intakes of protein and servings from the meat group than older firefighters. However, there were no significant differences for macronutrient intakes between the two age groups. Although Metro-Dade Firefighters' propensity for popular diets such as modified high-protein diets was based on hearsay, it was surprising to find that more than $20 \%$ were following a high-protein diet regimen.

Significantly more whites were overweight than non-whites. However, significantly more non-whites were obese than whites. A larger percentage of MetroDade Firefighters were overweight and obese compared to the general US population. Hence, Metro-Dade Firefighters may be at greater risk for CVD than the US population because of their higher prevalence of overweight and obesity.

Older male Metro-Dade Firefighters reported significantly more CVD risk factors than younger firefighters in the major non-modifiable, major modifiable, and total risk factor categories. Older, male, African-American Metro-Dade Firefighters that are obese are probably most at risk for CVD. Metro-Dade Firefighters are similar to the general US population in that most of the risk factors were modifiable and diet-related: overweight and obesity, high fat intakes, and low folate intake. Hence, it was found that Metro-Dade Firefighters seem to reflect the current general US population diet and overweight issues. 


\section{LITERATURE CITED}

AHA/ACC Scientific Statement: Assessment of Cardiovascular Risk by Use of MultipleRisk-Factor Assessment Equations, \#71-0177 Circulation. 1999;100:1481-1492 and JACC October 1, 1999.

American Heart Association. 2002 Heart and Stroke Statistical Update. Dallas, Tex.: American Heart Association; 2001.

American Heart Association. Cardiovascular diseases. Available at: http://www.amhrt.org/statistics/03cardio.html. Accessed March 31, 1999.

American Heart Association. The cholesterol facts. A summary of the evidence relating dietary fats, serum cholesterol, and coronary heart disease. A joint statement by American Heart Association and the National Heart, Lung, and Blood Institute. Circulation. 1990;81:1721-1733.

American Heart Organization. Cardiovascular risk factors. Available at: http://americanheart.org/statistics/08rskfct.html. Accessed on July 21, 1999.

Appel LJ, Moore TJ, Obarznek E, Vollmer WM, Svetkey LP, Sacks FM, Bray GA, Vogt TM, Cutler JA, Windhauser MM, Lin PH, Karanja N. A clinical trial of the effects of dietary pattern on blood pressure. DASH Collaborative Research Group. N Engl J Med. 1997;336:1117-1124.

Babu S, Srikantia SG. Availability of folates from some foods. Am J Clin Nutr. 1976;29:376-379.

Bazzano LA, He J, Ogden LG, Loria C, Vupputuri S, Myers L, Whelton PK. Dietary intake of folate and risk of stroke in US men and women: NHANES I Epidemiologic Follow-up Study. National Health and Nutrition Examination Survey. Stroke. 2002;33: 1183-1189.

Blankenship AT, Hagan RD. Taste-testing Demonstrations for firefighters. J Nutr Ed. 1986;18(suppl):S71-S72.

Block, G. A review of validations of dietary assessment methods. Am J Epidemiol. 1982;115:492-505.

Boushey, CJ, Beresford, SAA, Omenn, GS, Motulsky, AG. A quantitative assessment of plasma homocysteine as a risk factor for vascular disease: probable benefits of increasing folic acid intakes. J Am Med Assoc. 1995;274:1049-1057.

Brussard JH, Lowik MRH, den Berg H, Brants HAM, Goldbohlm RA. Folate intake and status among adults in the Netherlands. Eur J Clin Nutr. 1997;51(suppl):S46-S50. 
Castelli WP. Lipids, risk factors and ischemic heart disease. Atherosclerosis. 1996;12S.4(Suppl):S1-S9.

Centers for Disease Control and Prevention (CDC). Age-adjusted death rated for coronary heart disease: whites, Hispanics, Blacks, US and states, 1992-1995. Available at: Ftp://flpcdc.gov/pub/healthstatistics/ NCHS/Datasets/HealthyPeople2000/Mortality Objectives. Accessed on July 21, 1999.

Centers for Disease Control and Prevention (CDC). Behavioral Risk Factor Surveillance System Survey Data. Atlanta, Georgia: U.S. Department of Health and Human Services, Centers for Disease Control and Prevention, 1997.

Centers for Disease Control and Prevention. Monthly Vital Statistics Report, Vol 45, No 11(S)2, June 12, 1997. Available at: http://www.cdc.gov/NCHSwww/fastats/pdf/ 4511S224.pdf. Accessed on July 21, 1999.

Centers for Disease Control and Prevention. Monthly Vital Statistics Report., Vol 49, No 33, August 25, 2000. Available at: http://www.cdc.gov/NCHSwww/fastats/pdf/ 4933.pdf. Accessed on October 27, 2002.

Centers for Disease Control and Prevention. Nutrition and Physical Activity: Body Mass Index for Adults. http://www.cdc.gov/nccdphp/dnpa/bmi/bmi-adult.htm. Accessed on October 25, 2002.

Centers for Disease Control and Prevention. Prevalence of BMI, overweight and obesity: United States, 1960-1994. http://www.cdc.gov/nchs/data/nhanes/overweight.pdf. Accessed on October 25, 2002.

Centers for Disease Control and Prevention. Prevalence of overweight and obesity among US Adults, 1999-2000. http://www.cdc.gov/nchs/products/pubs/pubd/hestats/ obese/obse99.htm Accessed on October 25, 2002.

Chasen-Tuber L, Selhub J, Rosenberg IH, Malinow MR, Terry P, Tishler PV, Willett W, Hennekens $\mathrm{CH}$, Stampfer, MJ. A prospective study of folate and vitamin $\mathrm{B}_{6}$ and risk of myocardial infarction in US physicians. J Am Coll Nutr. 1996;15:136-143.

Cohen, J. Statistical Power Analysis for the Behavorial Sciences. $2^{\text {nd }}$ ed. Hillsdale, NJ: Lawrence Erlbaum Associates; 1988.

Colditz GA. Economic costs of obesity. Am J Clin Nutr. 1992;55:503S-507S. coronary heart disease in women. N Engl J Med. 1990;322:882-889.

Croft JB, Temple SP, Lankenau B, Heath GW, Macera CA, Baker ED, Wheeler FC. Community intervention and trends in dietary fat consumption among black and white adults. J Am Diet Assoc. 1994;94:1284-1290. 
Dalery K, Lussier-Cacan S, Selhub J, Davignon J, Latour Y, Genest J. Homocysteine and coronary artery disease in French Canadian subjects: relation with vitamins B12, B6, pyridoxal phosphate, and folate. Am J Cardiol. 1995;75:1107-1111.

Department of Health and Human services. Healthy People 2000; Progress review: Nutrition. February 3, 1998. http://odphp.osophs.dhhs.gov/pubs/hp2000/ PDF/prog_rvw/pr-nutri.pdf. Accessed March 31, 1999.

Einstein J, Roberts SB, Dallal G, Saltzman E. High-protein weight loss diets: are they safe and do they work? A review of experimental and epidemiologic data. Nutr Rev. 2002:60:189-200.

Eiserich JP, van der Vliet A, Handelman GJ, Halliwell B, Cross CE. Dietary antioxidants and cigarette smoke-induced biomolecular damage: a complex interaction. Am J Clin Nutr. 1995;62(6 Suppl):1490S-1500S.

Ernst ND, Obarznek E, Clark MB, Briefel RR, Brown CD, Donato K. Cardiovascular health risks related to overweight. J Am Diet Assoc. 1997;(Suppl):S47-S51.

Federal Register. Food standards: amendment of standards of identity for enriched grain products to require addition of folic acid. 1996;61:8781-8797.

Flegal KM, Carroll MD, Ogden CL, Johnson CL. Prevalence and trends in obesity among US adults, 1999-2000. JAMA. 2002;288:1723-7.

Ford ES, Ballew C. Dietary folate intake in US adults: findings from the third National Health and Nutrition Examination Survey. Ethn Dis. 1998;8:299-305.

Franke WD, Collins SA, Hinz PN. Cardiovascular disease morbidity in an Iowa law enforcement cohort, compared with the general Iowa population. J Occup Environ Med. 1998; 40:441-444.

Glueck CJ, Kelley W, Wang P, Gartside PS, Black D, Tracy T. Risk factors for coronary heart disease among firefighters in Cincinnati. Am J Ind Med. 1996;30:331-340.

Godlands IF, Leyva F, Walton C, Worthington M, Stevenson JC. Associations of smoking, alcohol and physical activity with risk factors for coronary heart disease and diabetes in the first follow-up cohort of the Heart Disease and Diabetes Indicators in a Screened Cohort study (HDSC-1). J Intern Med. 1998;244:33-41.

Green NS. Folic acid supplementation and prevention of birth defects. J Nutr. 2002;132:2356S-2360S.

Gregory JF. Bioavailability of folate. Eur J of Clin Nutr. 1997;51:S54-S59. 
Health, United States, 2002, table 70. Healthy weight, overweight, and obesity among persons 20 years of age and over, according to sex, age, race, and Hispanic origin: United States, 1960-62, 1971-74, 1976-80, 1988-94, and 1999-2000. http://www.cdc.gov/nchs/ data/hus/tables/2002/02hus070.pdf Accessed on October 25, 2002.

Healthy People 2010. Progress Review: Nutrition. Office of Disease Prevention and Health Promotion, U.S. Department of Health and Human Services. http://www.health. gov/healthypeople/data/PROGRVW/default.htm Accessed on October 25, 2002.

Healthy People 2010. Office of Disease Prevention and Health Promotion, U.S. Department of Health and Human Services. http://www.health.gov/healthypeople/ default.htm Accessed on October 25, 2002.

Heart and Stroke Facts: 1994 Statistical Supplement. Dallas, Tx: American Heart Association; 1994.

Hodges RE, Rebello T, Dietary changes and their possible effect on blood pressure. Am J Clin Nutr. 1985;41:1155-1162.

Institute of Medicine, Food and Nutrition Board. Dietary Reference Intakes for Energy, Carbohydrates, Fiber, Fat, Protein and Amino Acids (Macronutrients). National Academy Press, Washington, DC, 2002.

Institute of Medicine, Food and Nutrition Board. Dietary Reference Intakes: Vitamin A, Vitamin K, Arsenic, Boron, Chromium, Copper, Iodine, Iron, Manganese, Molybdenum, Nickel, Silicon, Vanadium, and Zinc. National Academy Press, Washington, DC, 2001.

Institute of Medicine, Food and Nutrition Board. Dietary Reference Intakes for Vitamin C, Vitamin E, Selenium, Cartenoids. National Academy Press, Washington, DC, 2000.

Institute of Medicine, Food and Nutrition Board. Dietary Reference Intakes for Calcium, Phosphorous, Magnesium, Vitamin D, Flouride, Thiamin, Riboflavin, Niacin, Vitamin B6, Folate, Vitamin B12, Pantothenic Acid, Biotin, and Choline. National Academy Press, Washington, DC, 1999.

Jacobsen DW. Determinants of hyperhomocysteinemia: a matter of nature annurture. Am J Clin Nutr. 1996;64:641-642.

Jacques PF, Sulsky SI, Sadowski JA, Phillips JCC, Rush D, and Willett WC. Comparison of micronutrient intake measured by a dietary questionnaire and biochemical indicators of micronutrient status. Am J Clin Nutr. 1993;57:182-189.

Johnson CL, Rifkind BM, Sempos CT. Declining serum cholesterol levels among US adults. JAMA. 1993;269:3002-3008. 
Joint National Committee on Detection, Evaluation, and Treatment of High Blood Pressure: The Fifth report of the Joint National Committee on Detection, Evaluation, and Treatment of High Blood Pressure. Arch Int Med. 1993;153:154-183.

Kales,SN, Polyhronopoulos GN, Aldrich JM, Leitao EO, Christiani DC.

Correlates of body mass index in hazardous materials firefighters. J Occup Environ Med 1999;41(7):589-595.

Kannel WB. Blood pressure as a cardiovascular risk factor: Prevention and treatment. JAMA. 1996;275:1571-1576.

Kannel WB. Host and environment determinants of hypertension. Perspectives from the Framingham Study. In Kesteloot H, Josen JH (eds): "Epidemiology of Arterial Blood Pressure." The Hague: Martinus-Nijhoff, 1980:265-295.

Kay, BF, Lund, MM, Taylor, PN, Herbold, NH. Assessment of firefighters' cardiovascular disease-related knowledge and behaviors. JADA. 2001;101:807-809.

Kjelsberg, MO, Cutler, JA, Dolecek TA. Chapter2. Brief description of the Multiple Risk Factor Intervention Trial. Am J Clin Nutr. 1997;65(suppl):191S-195S.

Kromhout D, Menotti A, Bloemberg B, Aravnis C, Blackburn H, Buzina R, Dontas AS, Fidanza F, Giampaoli S, Jansen A. Dietary saturated and trans fatty acids and cholesterol and 25-year mortality from coronary heart disease: the Seven Countries Study. Prev Med. 1995;24:308-315.

Kuczmarski RJ, Carroll MD, Flegal KM, Troiano RP. Varying body mass index cutoff points to describe overweight prevalence among US adults: NHANESIII (1988 to 1994). Obes Res. 1997;6:542-548.

Kuczmarski RJ, Flegal KM, Campbell SM, Johnson CL. Increasing prevalence of overweight among US adults: The National Health and Nutrition Examination Surveys, 1960 to 1991 . JAMA. $1994 ; 272: 205-211$.

Kumanyika SK. Diet and nutrition as influences on the morbidity/mortality gap. Ann Epidemiol. 1993;2:154-158.

Labarthe DR, Mueller WH, Elissa M. Blood pressure and obesity in childhood and adolescence: epidemiologic aspects. Ann Epidemiol. 1991;1:337-345.

Larsson B, Svardsudd K, Wilhelsen L, Bjorntorp P, Tibblin G. Abdominal adipose tissue distribution, obesity, and risk of cardiovascular disease and death; 13 year follow-up of participants in the study of men born in 1913. Br Med J. 1984;288:1401-1404. 
Leigh JP, Miller TR. Job-related diseases and occupations within a large workers' compensation data set. Am J Ind Med. 1998;33:197-211.

Lemaitre RN, Siscovivk DS, Raghunathan TE, Weinman S, Arbogast P, Lin DY. Leisure-time physical activity and the risk of primary cardiac rest. Arch Intern Med. 1999; 159:686-690.

Lenfant C, Ernst N. Daily dietary fat and total food-energy intakes- Third National Health and Examination Survey, Phase I, 1989-91. MMWR. 43:116-117, 123-125.

Licciardone JC, Hagan RD, Weiss S, Kaman RL, Taylor SC, Woodworth RM. Projected incidence of cardiovascular disease in male firefighters based on current risk factor prevalence. J Am Osteopath Assoc. 1989:89:1293-1294, 1297-1301.

Linn S, Carroll M, Johnson R, Kalsbeek W, Briefel R. High-density lipoprotein cholesterol and alcohol consumption in US white and black adults from NHANES II. Am J Public Health. 1993;83:811-816.

Locastro, Frank J. Nutrition knowledge, fat discrimination skills, and perceived health education needs of New York City firefighters. Columbia University Teachers College. DAI. 1989;50-11A:3490.

Manson JE, Colditz GA, Stampfer MJ. A prospective study of obesity and risk of coronary heart disease in women. N Engl J Med. 1990;322:882-889.

Melius JM. Cardiovascular disease among firefighters. Occup Med. 1995;10: $821-827$.

Melius JM. Occupational health for firefighters. Occup Med. 2001;16:101-108.

McCarron DA, Oparil S, Chait A, Haynes RB, Kris-Etherton P, Stern JS, Resnick LM, Clark S, Morris CD, Hatton DC, Metz JA, McMahon M, Holcomb S, Snyder GW. Comprehensive nutrition plan improves cardiovasculr risk factors in essential hypertension. Am J Hypertens. 1998; 11,31-40.

McNamara DJ. Dietary cholesterol and the optimal diet or reducing risk of atherosclerosis. Can J Cardiol. 1995;(Suppl G):123G-126G.

Morgan SA, O'Dea, Sinclair AJ. A low-fat diet supplemented with monounsaturated fat results in less HDL-C lowering than a very low-fat diet. J AM Diet Assoc. 1997;97:151156.

Muntwyler J, Hennekens CH, Manson JE, Buring JE, Gaziano JM. Vitamin supplement use in a low-risk population of US male physicians and subsequent cardiovascular mortality. Arch Intern Med. 2002;162(13): 1472-6. 
National Center for Health Statistics. Dietary Intake Source Data: United States, 19761980. Data from the National Health Survey. Washington, DC: US Dept. of Health and Human Services;1983. DHHS publication (PHS), 83-1681.

National Center for Health Statistics. Vital Statistics of the United States, 1989. Mortality, Part B. Vol II. Washington, DC: Public Health Service, US Government Printing office: 1992. DHHS publication (PHS), 92-1102.

National Institutes of Health. Clinical guidelines on the identification, evaluation, and treatment of overweight and obesity in adults. Bethesda, Maryland: Department of Health and Human Services, National Institutes of Health, National Heart, Lung, and Blood Institute, 1998.

National Research Council. Diet and Health: Implications for Reducing Chronic Disease Risk. Washington, DC: National Academy Press; 1989.

Nygard O, Vollset SE, Refsum H, Stensvold I, TveDRIl A, Nordhaug JE, Ueland PM, Kvale G. Total plasma homocysteine and cardiovascular risk profile: The HoDRIland homocysteine study. J Am Med Assoc. 1995;27:1526-1533.

Olson JA. Benefits and liabilities of vitamin A and carotenoids. J Nutr 1996;126:1208S$12 \mathrm{~S}$.

Oshaug A, Bugge KH, Refsum H. Diet: an independent determinant for plasma total homocysteine: A cross sectional study of Norwegian workers on platforms in the North Sea. Eur J Clin Nutr. 1998;52:7-11.

Oster G, Thompson, D. Estimated effects of reducing dietary saturated fat intake on the incidence and costs of coronary heart disease in the United States. J Am Diet Assoc. 1996;96:127-131.

Paffenbarger, RS, Hyde, RT, Wong AL, Lee IM, Jung DL, Kampert JB. The association of changes in physical-activity level and other lifestyle characteristics with mortality among men. N Engl J Med. 1993;328:538:545.

Pancharuniti N, Lewis CA, Sauberlich HE, Perkins LL, Go RCP, Alvarez JO, Macaluso M, Acton RT, Copeland RB, Cousins AL, Gore TB, Cornwell PE, Roseman JM. Plasma homocyst(e)ine, folate, and vitamin B12 concentrations and risk for early onset coronary artery disease. Am J Clin Nutr. 1994;59:940-948

Pi-Sunyer FX. Health implication of obesity. Am J Clin Nutr. 1991;53:1595S-1603S.

Piyathilake CJ, Macaluso M, Hine RJ, Richards EW, Krumdieck CL. Local and systemic effects of cigarette smoking on folate and vitamin 12. Am J Clin Nutr. 1994;60:559-566. 
Preuss HG, Gondal JA, Lieberman S. Association of macronutrients and energy intake with hypertension. J Am Coll Nutr. 1996;15:21-35.

Reddy ST, Wang CY, Sakhaeek K, Brinkly L, Pak CY. Effect of low-carbohydrate highprotein diets on acid-base balance, stone-forming propensity, and calcium metabolism. Am J Kidney Dis. 2002;40:265-274.

Reisin E, Frohlich ED, Messerli FH, Dreslinski GR, Dunn FG, Jones MM, Batson HM Jr. Cardiovascular changes after weight reduction in obesity hypertension. Ann Intern Med. 1983;98:315-319.

Rissanen A, Heliovaara M, Knekt O, Aromaa A, Revanen A Maatela J. Weight and mortality in Finnish men. J Clin Epidemiol. 1989;42:781-789.

Schectman G, Byrd JC, Hoffmann R. Ascorbic acid requirements for smokers: analysis of a population survey. Am J Clin Nutr. 1991:53(6):1466-70

Selhub J, Jacques PF, Bostom AG, S'Agostino RB, Wilson PWF, Belanger AJ, O'Leary, DH, Schaefer EJ, and Rosenberg, IH. Association between plasma homocysteine concentrations and extra-cranial carotid-artery stenosis. N Engl J Med. 1995;332:286291.

Selhub J, Jacques PF, Wilson PWF, Rush D, and Rosenberg IH. Vitamin status and intake as primary determinants of homocysteinemia in the elderly population. J Am Med Assoc. 1993;270:2693-2698.

Stamler J. Epidemiologic findings on body mass and blood pressure in adults. Ann Epidemiol. 1991;1:347-362.

Stamler R, Stamler J, Riedlinger WF, Alegera G, Roberts RM. Weight and blood pressure. Findings in hypertension screening of 1 million Americans. JAMA. 1978;240:1607-1610.

Subar AF, Block G, James LD. Folate intake and folate sources in the US population. Am Clin Nutr. 1989;50:508-516.

Subar AF, Thompson FE, Kipnis V, Midthune D, Hurwitz P, McNutt S, McIntosh A, Rosenfeld S. Comparative validation of the Block, Willet and National Cancer Institute Food-frequency Questionaires. Am J Epidemiol. 2001;154:1089-1999.

Tuchsen F, Andersen O, Costa G, Filakti H, Marmot MG. Occupation and ischemic heart disease in the European Community: a comparative study of occupations at potential high risk. Am J Ind Med. 1996;30:407-414. 
Tucker KL, Selhub J, Wilson PF, Rosenberg IH. Dietary intake pattern relates to plasma folate and homocysteine concentrations in the Framingham Heart Study. J Nutr. 1996;126:3025-3031.

Tuomilheto J, Zimmer P, taylor r, Bennett P, Kankaanpaa J, Wolfe E. A cross-sectional ecological analysis of blood pressure and its determinants in eleven Pacific populations. $\mathbf{J}$ Am Coll Nutr. 1989:8:151-165.

USDA/ARS (US Department of Agriculture, Agriculture Research Service). $2000 \mathrm{~b}$.

Pyramid Servings Intakes by Children and Adults: 1994-96, 1998. Online. ARS

Community Nutrition Research Group Web site, available at: http://www.barc.usda.gov/ bhnrc/cnrg/. Accessed March 31, 1999

Van Itallie TB. Health implications of overweight and obesity in the United States. Ann Intern Med. 1985; 103:983-988.

Verhoef P, Stampfer MJ, Buring JE, Gaziano JM, Allen, RH, Stabler AP, Reynolds RD, Kok, FJ, Hannekens CH, Willett, WC. Homocysteine metabolism and risk of myocardial infarction: Relation with vitamin $\mathrm{B}_{6}, \mathrm{~B}_{12}$, and Folate. Am J Epidemiol. 1998;9:845-859.

Weiss S, Hagan RD, Kaman RL, Taylor SC, Woodworth RM. Age-related changes of coronary heart disease risk factors in municipal firefighters. Med Sci Sports Exerc. 1984;16:195-196.

Wende, KE. A study of mortality among city of Buffalo Firefighters [New York]. State University of New York at Buffalo. DAI. 1996;57-01B:0251.

Willett WC, Reynolds RD, Cottrell-Hoehner S, Sampson L, and Brown ML. Validation of a semi-quantitave food-frequency questionnaire: comparison with a one-year diet record. J Am Diet Assoc. 1987;87: 43-47.

Willett WC, Sampson L, Stampfer MJ, Rosner B, Bain C, Witschi J, Hennekens CH, Speizer FE. Reproducibility and validity of a semiquantitative food-frequency questionnaire. J Am Epidemiology. 1985;122:51-65.

Winton, SJ. A worksite nutrition education program increased firefighters' knowledge \& resulted in healthier attitudes toward fad diets. Master of Science in Dietetics and Nutrition Thesis. Florida International University, 2002. 


\section{INFORMED CONSENT}

\section{DIETARY FOLATE INTAKE OF FIREFIGHTERS IN METRO-DADE COUNTY AND THEIR RISK FOR CARDIOVASCULAR DISEASE}

YOU ARE ASKED TO READ THE FOLLOWING FORM TO MAKE SURE THAT YOU COMPLETELY UNDERSTAND WHAT WILL HAPPEN IF YOU AGREE TO TAKE PART IN THIS STUDY. SIGNING THIS FORM MEANS THAT THE STUDY HAS BEEN EXPLAINED TO YOU AND THAT YOU GIVE YOUR PERMISSION TO TAKE PART. THE FEDERAL GOVERNMENT REQUIRES YOUR APPROVAL IN WRITING BEFORE TAKING PART IN ANY RESEARCH STUDY. IT IS IMPORANT THAT YOU WILL KNOW WHAT WILL TAKE PLACE AND WHAT RISKS ARE INVOLVED BEFORE YOU DECIDE TO WHETHER OR NOT TO TAKE PART IN THIS STUDY.

\section{RESEARCH PURPOSE AND DURATION}

The research entitled, "Dietary folate intake of firefighters in Metro-Dade County and their risk for cardiovascular disease is to be conducted by Kathrine Berdebes and Fatma G. Huffman, PH, RD, as Principal Investigators from Florida International University. This research will last approximately 30 minutes. There will be approximately 150 participants in the total sample.

The purpose is to determine folate intake and prevalent cardiovascular risk factors of firefighters in Metro-Dade County. We will also determine what composes their diet.

\section{PROCEDURES}

You will be asked to complete two questionnaires. One will include questions on sociodemographic data and questions related to cardiovascular disease risk factors. The second questionnaire will include questions pertaining to your diet. You will then be weighed measured on a calibrated scale located at the fire station.

\section{RISKS OF DISCOMFORTS}

There are no risks or discomforts involved in your participation in this research study.

\section{BENEFITS TO YOU}

Although it may not directly benefit you to participate, this study will contribute knowledge about diet compositions, folate intakes, and cardiovascular disease risks factors for firefighters. After completion of the study, the researcher will provide a nutrient analysis to firefighters who participated in the study and are interested in receiving a copy. 


\section{COSTS TO YOU FOR TAKING PART IN THIS RESEARCH STUDY}

There will be no cost to you for taking part in this research study.

\section{PAYMENT FOR TAKING PART IN THIS RESEARCH STUDY}

You will not be paid for taking part in the research study.

\section{CONFIDENTIALITY}

All information, which refers to, or can be identified with you, will remain confidential to the extent permitted by law. No information will be revealed about you or your part in this study, without your permission or the permission of your legally authorized representative, except that which may be necessary for the Research Committee to satisfy their legal responsibility for review of the project.

\section{COMPENSATION FOR RESEARCH RELATED INJURY}

Financial compensation for research-related injury or loss of wages is not available.

\section{WHOM TO CONTACT FOR ANSWERS}

If you desire further information about this research contact Fatma Huffman, PhD, RD, Florida International University, (305) 348-2878, Kathrine Berdebes, (305) 408-1785, David Lee, Director of the Firefighter Health Project, University of Miami, (305) 2436980 or Lt. Guy Ritter, Station 28B, (305) 821-0612.

\section{PARTICIPATION IS VOLUNTARY}

Your participation in this study is voluntary. If you wish, you may choose not to take part in this study. You may withdraw consent and discontinue participation in this research project at any time without any negative consequences.

\section{I HAVE READ, UNDERSTOOD, AND RECEIVED A COPY OF THIS INFORMED CONSENT FORM AND AGREE TO PARTICIPATE IN THIS STUDY.}

Principal Investigator

Date

Fire Station Number

Telephone Number $\overline{\text { Participant Date }}$

Shift (A, B, or C)

Witness

Date

Please check one

Yes, I am willing to provide my name so that the nutrient analysis report can be sent to me.

No. I do not want the report.

ID \# 
ID \#

By completing the following questionnaires, you are agreeing to participate in this study.

Please, read the following questions and answer as best as you can. Please check one answer only.

1. Sex:

$$
\begin{array}{ll}
\text { a } & \text { Male } \\
\text { - } & \text { Female }
\end{array}
$$

2. How old are you? Years

3. How long have you been employed as a firefighter? Years

4. Race and ethnic background:
व White not Hispanic origin
口 Hispanic
口 Black, not Hispanic origin
口 Other

5. What level of education did you complete?
- Completed High School
- Some College
- Associate Degree
口 Bachelor Degree
口 Post-Graduate

6. How long have you been in the United States?
口 Less than six months
a Six to 11 months
a One to three years
a Four to five years
․ More than five years
a All of my life

7. Family history of heart disease (check first correct answer):

- Three relatives with heart disease before 60 years of age.

- Two relatives with heart disease before 60 years of age.

a One relative with heart disease before 60 years of age.

- Three relatives with heart disease after 60 years of age.

a Two relatives with heart disease after 60 years of age.

a One relative with heart disease after 60 years of age.

a You have no family history of heart disease

a You don't know your family history of heart disease. 
ID \#

8. Personal History of heart disease:

- You have had or have been diagnosed to have heart disease.

व You have never had heart disease.

9. Family history of diabetes (check first correct answer):

- You have diabetes that began before the age of 20 .

- You have diabetes that began between the ages 20-60.

a You have diabetes that began after the age of 60 .

- You have two relatives with diabetes.

a You have one relative with diabetes.

- You have no family history of diabetes.

a You don't know your family history of diabetes.

10. Smoking habits (check one only):

a You have never smoked cigarettes, cigars, or pipes.

a You have quit smoking cigarettes at least one year ago or you now smoke cigars or pipes without inhaling smoke.

- You have quit smoking cigarettes within one year or now smoke less than 10 cigarettes per day.

- You smoke 20 cigarettes per day (one pack).

a You smoke 30 cigarettes per day (one $1 / 2$ packs).

- You smoke 40 cigarettes per day (two packs).

11. Activity level:

口 Inactive: No regular physical activity with a sitting down job, including hospitalized patients.

a Light: No organized physical activity during leisure time with three to four hours of walking or standing per day.

- Moderate: Sporadically involved in recreational activities such as weekend golf or tennis, occasional jogging, swimming or cycling.

a Heavy: Consistent job activities of lifting or stair climbing or participating regularly in recreational/fitness activities such as jogging, swimming or cycling at least three times per week for 30 to 60 minutes per session.

a Vigorous: Participation intensive physical activity for 60 minutes or more at Least four times per week.

12. Are you taking any prescription medicines?

Yes, (please specify)

No 
ID \#

To be completed by researcher only

13. Height: inches

14. Weight: pounds

BMI: $\quad$ WT $(\mathrm{kg})$ $\mathrm{kg} / \mathrm{m}^{2}$ $\mathrm{HT}\left(\mathrm{m}^{2}\right)$ 